\title{
Effect of the catalyst in the BTX production by hydrocracking of light cycle oil
}

\author{
Georgina C. Laredo ${ }^{1}$ (D . José L. García-Gutiérrez ${ }^{1} \cdot$ Patricia Pérez-Romo $^{1} \cdot$ Eli H. Olmos-Cerda ${ }^{1}$
}

Received: 14 October 2020 / Accepted: 8 February 2021 / Published online: 2 March 2021

(C) The Author(s) 2021

\begin{abstract}
Catalysts to produce the important petrochemicals like benzene, toluene, and xylene (BTX) from refinery feedstocks, like light cycle oil (LCO) are reviewed here by covering published papers using model mixtures and real feeds. Model compounds experiments like tetralin and naphthalene derivatives provided a 53-55\% total BTX yield. Higher yields were never attained due to the inevitable gas formation and other $\mathrm{C}_{9+}$-alkylbenzenes formed. For tetralin, the best catalysts are those conformed by $\mathrm{Ni}$, CoMo, NiMo, or NiSn over zeolite H-Beta. For naphthalene derivatives, the best catalysts were those conformed by W and NiW over zeolite H-Beta silylated. Real feeds produced a total BTX yield of up to $35 \%$ at the best experimental conditions. Higher yields were never reached due to the presence of other types of hydrocarbons in the feed which can compete for the catalytic sites. The best catalysts were those conformed by Mo, CoMo, or NiMo over zeolite H-Beta. Some improvements were obtained by adding ZSM-5 to the support or in mixtures with other catalysts.
\end{abstract}

Keywords Light cycle oil $\cdot$ Hydrogenation $\cdot$ Hydrocracking $\cdot$ BTX

\section{Introduction}

The production of benzene, toluene, and xylene (BTX) from light cycle oil (LCO) has been our matter of interest in the last years [1-4]. LCO, a middle distillate from FCC (fluid catalytic cracking), has lost market as a part of the diesel feedstock due to its inherent low quality (high sulfur, nitrogen, and aromatic contents) [5-7], which makes the resulting fuel difficult to comply with the stringent worldwide environmental regulations [8, 9]. In Mexico, LCO can contain up to $90 \%$ of mono-, di- and tri-aromatic compounds [6, 7], being most of these compounds di-aromatic hydrocarbons, i.e. naphthalene derivatives [7]. Among the alternatives for LCO upgrading, the production of BTX after successive hydrotreating (HDT)

Georgina C. Laredo

glaredo@imp.mx

José L. García-Gutiérrez

garciajl@imp.mx

Patricia Pérez-Romo

pperezr@imp.mx

Eli H. Olmos-Cerda

eholmos@imp.mx

1 Instituto Mexicano del Petróleo, Lázaro Cárdenas 152, 07730 CDMX Mexico, Mexico and hydrocracking (HCK) procedures (Fig. 1) $[1,2,10]$ has been studied either using model mixtures $[1,3]$ or in a lesser extent using real feeds [2, 4]. Additionally, it is well known [1, $2,10]$ that catalysts play a key role in the hydrogenation (partial saturation) of naphthalene followed by the selective cracking of naphthenic structures, producing one-ring-aromatic hydrocarbons with alkyl chains. For this purpose, bifunctional catalysts with acid (support) and metal (hydrogenation-dehydrogenation) functions are frequently used [11, 12]. However, an excess of hydrogenation activity, and strong acidity may crack molecules excessively into light gaseous hydrocarbons and accelerate coke deposition. In this sense, hydrocracking catalysts with metal (groups VI and VIII) sulfides perform, in general, the hydrodehydrogenation, and hydrocracking of heavy oil feedstocks. For this reason, metallic-sulfide-supported catalysts are considered more effective materials than metals [12,13]. Another key parameter that may influence the activity of bimetallic over the corresponding monometallic catalyst is the ratio of the constituents' metals (e.g. Ni to Co ratio) [14].

Zeolites are widely preferred over other supports because of their stronger acidity, higher thermal, and hydro-thermal stability, higher resistance to sulfur and nitrogen compounds, reduced coke production tendency and higher regeneration capability [12]. Additionally, the porosity of zeolites allows their unique shape selectivity characteristic, i.e. certain 
Fig. 1 Reaction scheme for obtaining BTX, LP, and naphtha from naphthalene derivatives in the LCO

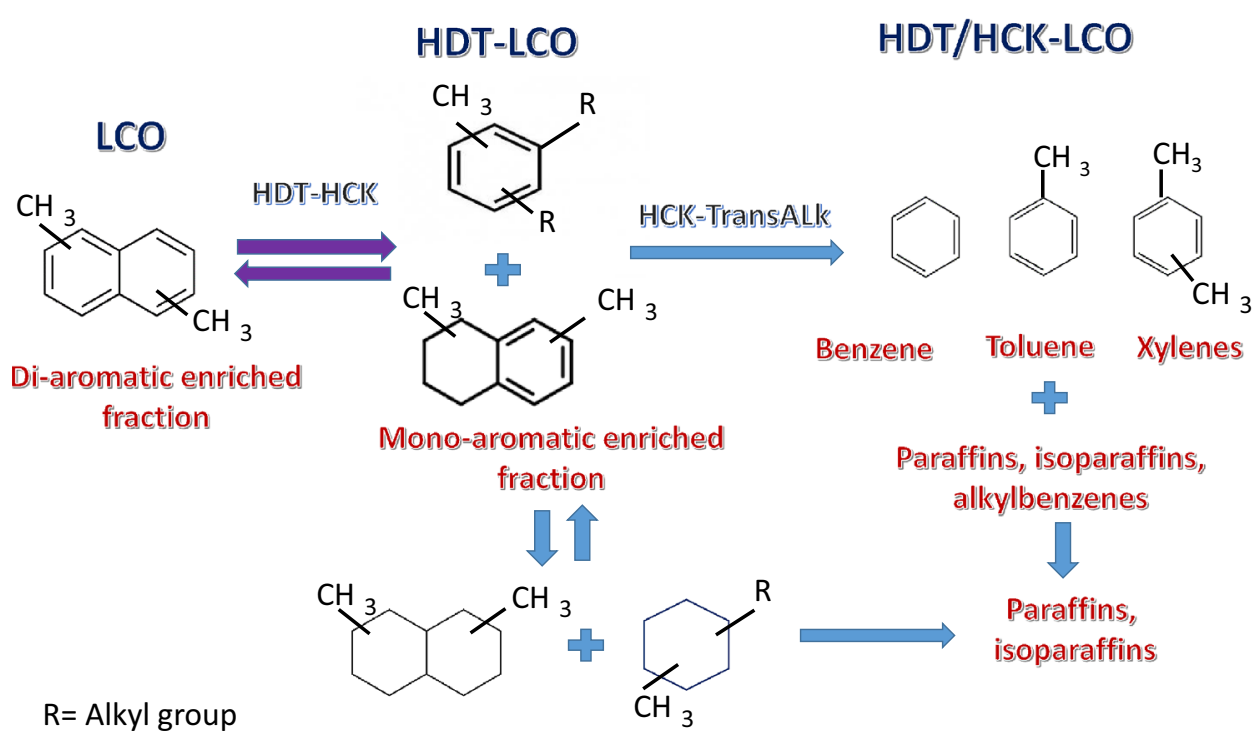

reactions are facilitated while others are suppressed. Acidity can significantly influence the selectivity of catalysts, as for example, the distribution of microporous Brønsted acidity seemed to affect the shape-selectivity in a catalyst [15]. Therefore, a balance between acid functions and metal functions may seem to be a requirement for an optimal catalytic performance.

The initial objective of this work is to make a careful revision of the developed catalyst for the BTX production when they were studied using model molecules like tetralin, naphthalene, and naphthalene derivatives, and real feeds such as hydrotreated and nonhydrotreated light cycle oil (HDT LCO and LCO).

Therefore, the main objective of this review is the focusing on the possible correlations between catalyst chemical characteristics strictly in the BTX yield, while previous descriptions $[1,2]$ were more general as debating catalyst, products, and chemical conditions for petrochemicals, and fuel production from model, and real feeds. The task here was to gather all the information available regarding synthetized single metal, mixed metal, and non-metallic additivities catalysts, and their compositions, surface characteristics (total surface and pore volume) and acidic properties (Brønsted/Lewis acidity). With this information available, it was expected to reach a decision regarding the best catalyst up to date to attain scientifically, the highest BTX production through correlations.

\section{Theoretical considerations}

\section{Maximum BTX production from model molecules}

Tetralin: $1 \mathrm{~mol}$ of tetralin $(132.2 \mathrm{~g})$ will produce according to previous experiments [3,4] approximately 0.1, 0.4, 0.18. 0.09 and $0.08 \mathrm{~mol}$ of benzene, toluene, $\mathrm{p}-\mathrm{m}$ - and o-xylenes, respectively.
After multiplying for their respective molecular weights $(78,92$, and $106 \mathrm{~g} / \mathrm{mol}$ ) it was calculated a $63 \%$ theoretical conversion.

Naphthalene: $1 \mathrm{~mol}$ of naphthalene $(128.1 \mathrm{~g})$ will produce according to previous experiments $[3,4]$ approximately 0.1 , 0.4, 0.18. 0.09 and $0.08 \mathrm{~mol}$ of benzene, toluene, $\mathrm{p}$-, $\mathrm{m}$ - and o-xylenes, respectively. After multiplying for their respective molecular weights $(78,92$, and 106) it was calculated a total of 83.5 , then a $65 \%$ theoretical conversion.

\section{BTX equations used for comparison.}

To perform a comparison, the total $\mathrm{X}$ yields $\left(\mathrm{X}_{\mathrm{Y}}\right)$ were calculated when the data was available, by multiplying the hydrocracking conversion $\left(\mathrm{HCK}_{\mathrm{C}}\right)$ by the $\mathrm{X}$ selectivity $\left(\mathrm{X}_{\mathrm{S}}\right)$ (Eq. 1.) where the X can be: BTX (BTX), light hydrocarbons i.e. paraffin and isoparaffin derivatives (LP), non-aromatic hydrocarbons i.e. naphthenes (HYD), $\mathrm{C}_{9+}$-alkylbenzenes $\left(\mathrm{C}_{9+} \mathrm{ALB}\right)$, tetralin and indene type compounds (TI), and heavy hydrocarbons, i.e. naphthalene, phenanthrene derivatives $(\mathrm{HH})$. In some cases, mainly in the real feed studies, the liquid fraction (LF) was also considered (Eq. 2). And a more accurate yield could be obtained $\left(\mathrm{X}_{\mathrm{YLF}}\right)$ :

$\mathrm{X}_{\mathrm{Y}}(\%)=\mathrm{HCK}_{\mathrm{C}} \times \mathrm{X}_{\mathrm{S}} / 100$

$\mathrm{X}_{\mathrm{YLF}}=\mathrm{X}_{\mathrm{Y}} \times \mathrm{LF} / 100$

\section{Results and discussion}

\section{BTX production from tetralin}

A summary of the characteristics of the catalyst prepared for BTX production from tetralin is shown in Table 1 . 
The order of the references depended on the time of publication.

\section{Effect of the acidity of the support}

Sato et al. [16, 17] studied the effect of different supports, USY, HY, and mordenite (MOR) on a NiW catalyst. The loading of $\mathrm{NiW}\left(\mathrm{NiO}-3.5 \%, \mathrm{WO}_{3}-24.0 \%\right)$ was performed by the usual incipient wetness technique. The testing of the materials was as follows: batch reactor, temperature: $350{ }^{\circ} \mathrm{C}$, reaction time: $1 \mathrm{~h}$, catalyst weight: $0.3 \mathrm{~g}$, tetralin: $5 \mathrm{~mL}$, initial $\mathrm{H}_{2}$ pressure: 6.1 MPa. The best performance for producing BTX in this work was obtained after using the NiW/USY with a $45 \%$ tetralin conversion that provided a $9 \%$ total BTX yield, followed by the NiW/HY with a $4 \%$ (23\% tetralin conversion). The NiW/MOR only provided $1.5 \%$ of BTX. Instead of BTX, NiW/USY and NiW/HY produced heavy compounds $(\mathrm{HH})$ as the main product with a 20 and $13 \%$ total yield. NiW/MOR due to the extremely low tetralin conversion (10\%), formed only, besides BTX, $1.5 \%$ of indanes (TI), and $1.5 \%$ of heavy compounds $(\mathrm{HH})$. The material on $\mathrm{Al}_{2} \mathrm{O}_{3}$ did not provide $\mathrm{BTX}$ but decalin $(41,95$, and $39 \%$ for conversion, selectivity, and total yield, respectively). They conclude that the ring-opening (RO) of tetralin needs relatively strong acid sites. Comparing the two zeolites with strong acidity, the acid sites of USY function for hydrocracking of tetralin, whereas those of MOR catalyze isomerization or excess cracking to gaseous products. The high hydrocracking activity of USY may be related to the hydrogen transferability of USY. In tetralin hydrocracking, NiW hydrogenates aromatic compounds which are the result of the tetralin dehydrogenation.

Ferraz et al. [18] prepared three NiMo catalysts by wet impregnation of the following extruded supports: pure alumina (Alu), silica-alumina ( $\mathrm{SiAl}$ ), and $\mathrm{Y}$ zeolite $(30 \%$, $\mathrm{SiO}_{2} / \mathrm{Al}_{2} \mathrm{O}_{3}=13.7 \mathrm{~mol} / \mathrm{mol}$ ) on alumina (AluZ). All the extruded supports were previously calcined at $550{ }^{\circ} \mathrm{C}$. Catalysts were prepared by successive molybdenum nickel impregnation with the following metal content: $20 \% \mathrm{MoO}_{3}$ and $4 \% \mathrm{NiO}$. First, a solution of $\left(\mathrm{NH}_{4}\right)_{6} \mathrm{Mo}_{7} \mathrm{O}_{24}$ followed by $\mathrm{Ni}\left(\mathrm{NO}_{3}\right)_{2} \cdot 6 \mathrm{H}_{2} \mathrm{O}$. Experimental tests were conducted in a fixed bed reactor at $310{ }^{\circ} \mathrm{C}, 4 \mathrm{MPa}$ pressure, WHSV of $4 \mathrm{~h}^{-1}$, feed flow rate of $13.5 \mathrm{~mL} / \mathrm{h}$, and $600 \mathrm{~N} \mathrm{~mL} / \mathrm{min}$ of hydrogen. The observed total BTX yields were $0.2,2$, and $16 \%$ for the $\mathrm{NiMo} / \mathrm{Alu}, \mathrm{NiMo} / \mathrm{SiAl}$, and $\mathrm{NiMo} / \mathrm{AluZ}$, respectively. They observed an increase in the global conversion of tetralin with increased support acidity. This increase was observed both for the formation of aromatic hydrocarbons and for the hydrogenated compounds (HYD), being the last ones the main products with total yields of 5, 6, and $11 \mathrm{wt} . \%$ for the NiMo/Alu, NiMo/SiAl, and NiMo/AluZ, respectively. The higher yield of aromatic products when acid supports were used was assigned to the protonation of the tetralin molecule, which leads to isomerization, naphthenic ring-opening, and cracking reactions. The yield of cracking products, especially benzene, with the NiMoS/AluZ catalyst increased significantly even in moderate tetralin conversions $(19,28$, and 53\%).

Laredo et al. [3] prepared mixtures using pellets of a commercial NiMo/ $/ \mathrm{Al}_{2} \mathrm{O}_{3}$ catalyst with ZSM-5 zeolite that were crushed, sieved to $40 / 60$ mesh, dried in an oven at $120{ }^{\circ} \mathrm{C}$ for $2 \mathrm{~h}$, and then tested separately and in mixtures of 20/80, 30/70, and 50/50 NiMo/zeolite wt.\% ratios. The total BTX yield went from $10 \%$ for the $\mathrm{NiMo} / \mathrm{Al}_{2} \mathrm{O}_{3}$ alone to $59 \%$ with the ZSM-5. NiMo/ZSM-5 mixtures provided 35, 45, and $53 \%$ for the 50/50,30/70 and 20/80 mixtures, respectively, at $500{ }^{\circ} \mathrm{C}, 4.9 \mathrm{MPa}, \mathrm{H}_{2} /$ feed volume ratio of $267 \mathrm{~m}^{3} / \mathrm{m}^{3}$, and LHSV of $1.3 \mathrm{~h}^{-1}$. The main secondary product was naphthalene with a presence of 23,15 , and $13 \%$, in the same order. Some hydrogenated products like decalin were produced in the following order: 0,7 , and $4 \%$. As higher was the zeolite content, the higher the Brønsted acidity and the higher the BTX total yield. However, the deactivation of the catalyst due to the lack of metallic function was also faster.

\section{Effect of the support structure}

Sato et al. [19] prepared over two kinds of HY zeolites obtained after ion-exchanged cycles using an aqueous solution of ammonium sulfate $(3 \mathrm{~mol} / \mathrm{L})$ at $95{ }^{\circ} \mathrm{C}$ from a commercial $\mathrm{NaY}(\mathrm{TO})$ with a framework $\mathrm{Si} / \mathrm{Al}$ ratio of 2.8 , and $\mathrm{NaY}(\mathrm{CE})$ with a framework $\mathrm{Si} / \mathrm{Al}$ ratio of 4.1 . The supports were prepared by hydrothermal synthesis using 15 -crown- 5 as a template. $\mathrm{NiMo} / \mathrm{HY}$ catalysts $(\mathrm{NiO}=1.7 \%$, $\mathrm{MoO}_{3}=6.7 \%$ ) by a successive molybdenum nickel impregnation method using aqueous solutions of $\left(\mathrm{NH}_{4}\right)_{6} \mathrm{Mo}_{7} \mathrm{O}_{24}$ and $\mathrm{Ni}\left(\mathrm{NO}_{3}\right)_{2} \cdot 6 \mathrm{H}_{2} \mathrm{O}$, then drying, calcining, and sulfiding prior to the test $\left(400{ }^{\circ} \mathrm{C}, 5 \% \mathrm{H}_{2} \mathrm{~S} / \mathrm{H}_{2}\right.$, atmospheric pressure, $2 \mathrm{~h}$ ). Both zeolites were found to possess similar micropore structures, but different mesopore structures. For both catalysts, the majority of NiMo sulfides were dispersed in the micropores of zeolites. In the $\mathrm{NiMo} / \mathrm{HY}(\mathrm{TO})$ with mesopores, NiMo sulfides were also located inside the mesopores, whereas in the $\mathrm{NiMo/HY}(\mathrm{CE})$, NiMo sulfides were deposited on the external surface of zeolite particles. The hydrocracking of tetralin was carried out in an autoclave with an electric furnace that was waved with a rocking system during the reaction. The experimental conditions were as follows: $5 \mathrm{~mL}$ of tetralin, $0.3 \mathrm{~g}$ of catalyst, initial hydrogen pressure of $5.9 \mathrm{MPa}$, reaction temperature of $350{ }^{\circ} \mathrm{C}$, and reaction time of 5-60 min. After the reaction, no significant difference was observed in the catalytic activities of the two NiMo/HY catalysts, being the BTX total yield of $13 \%$ for $\mathrm{NiMo} / \mathrm{HY}(\mathrm{TO})$ and $11 \%$ for $\mathrm{NiMo} / \mathrm{HY}(\mathrm{CE})$. As in their previous works $[16,17]$ the main product was not

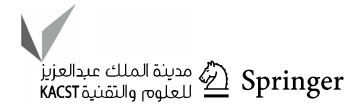




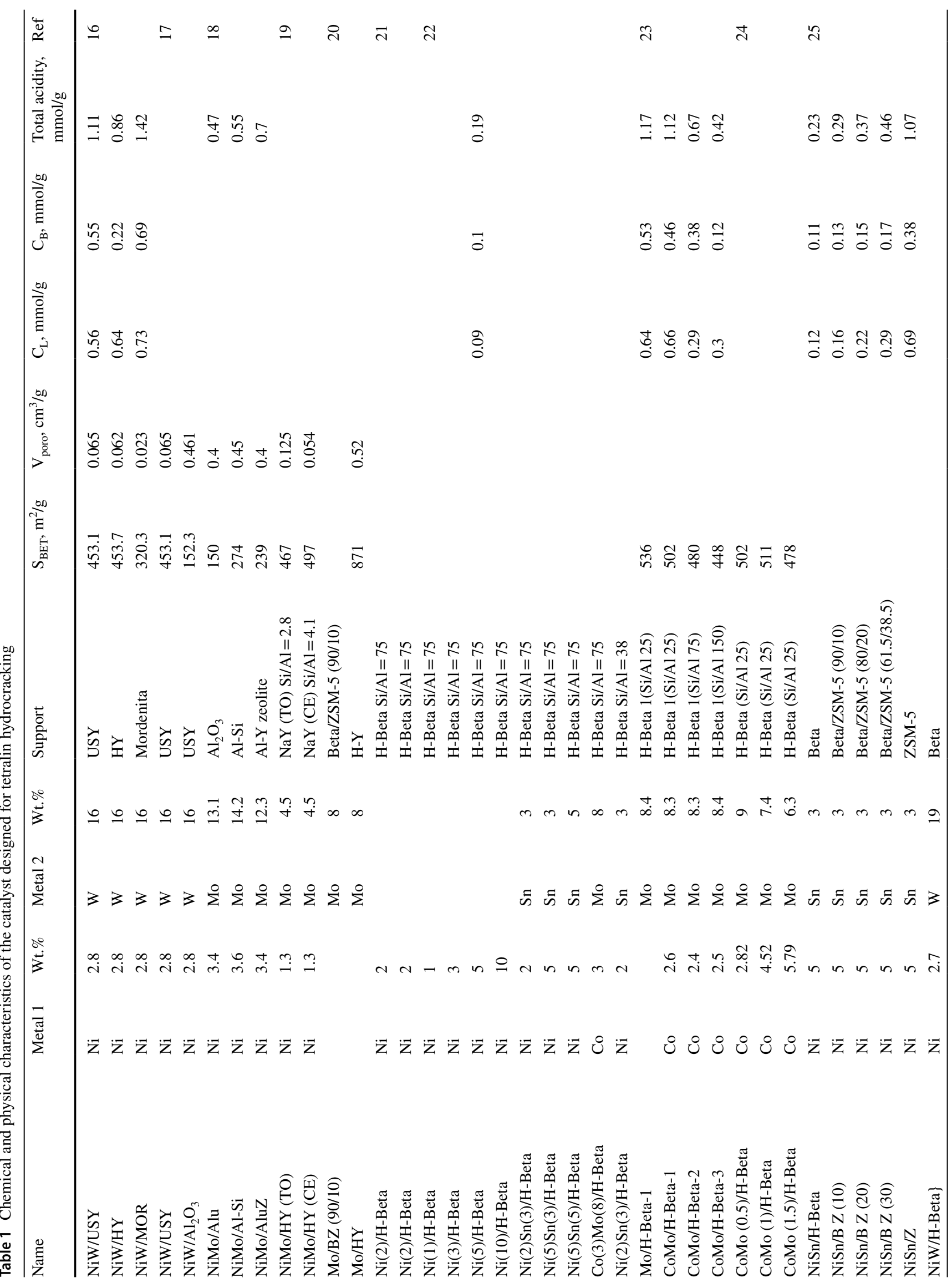




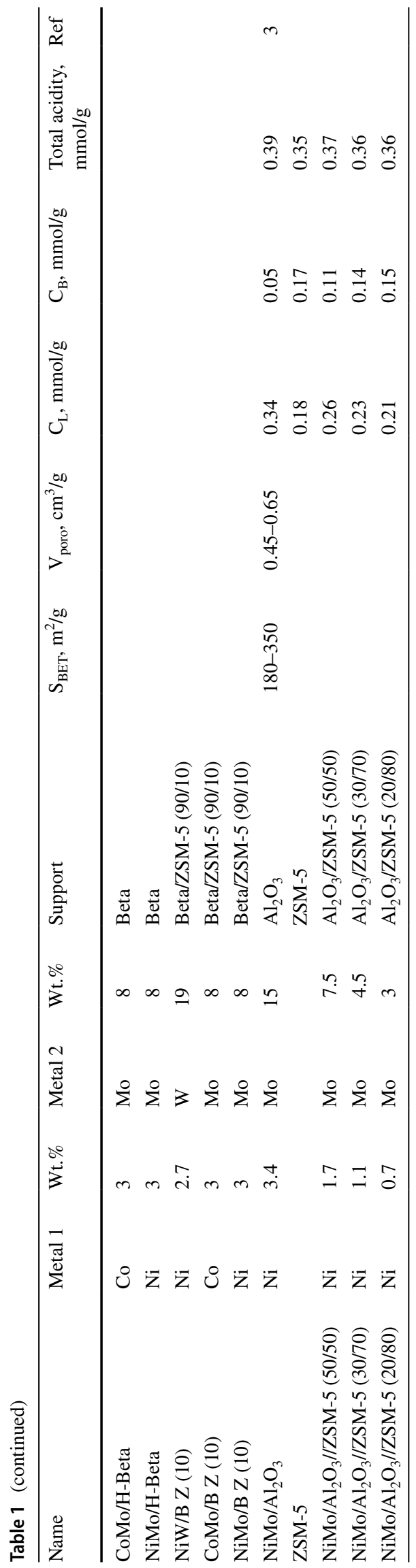

BTX but heavy compounds (HH), present in amounts of approximately 25 and $23 \%$ respectively, while the tetralin conversion was 50 and $45 \%$, in the same order. Apparently, the inherent similarity of microporous structures generates similar catalytic activities [12].

Recently, Oh et al. [20] published the results of the hydrocracking of tetralin using molybdenum (8 wt.\%; $\left.\left(\mathrm{NH}_{4}\right)_{6} \mathrm{Mo}_{7} \mathrm{O}_{24} \cdot 4 \mathrm{H}_{2} \mathrm{O}\right)$ on a hybrid zeolite formed by H-Beta $\left(\mathrm{SiO}_{2} / \mathrm{Al}_{2} \mathrm{O}_{3}=75\right)$ and HZSM-5 $\left(\mathrm{SiO}_{2} / \mathrm{Al}_{2} \mathrm{O}_{3}=30\right)$ in a 90/10 in weight mechanical mixture, and on an $\mathrm{HY}$ (FAU structure, $\mathrm{SiO}_{2} / \mathrm{Al}_{2} \mathrm{O}_{3}=80$ ) by wet impregnation. They studied these catalysts using tetralin as a model compound to observe the effect of mesoporosity in the hydrocracking process at the following experimental conditions: $450{ }^{\circ} \mathrm{C}$, WHSV $=2.0 \mathrm{~h}^{-1}$, total pressure $=6 \mathrm{MPa}, \mathrm{H}_{2} /$ feed $=1972 \mathrm{~mL} / \mathrm{mL}$. A temperature of $450{ }^{\circ} \mathrm{C}$ was required for the Mo-S/H-Y catalyst to achieve the near-complete conversion of tetralin because of the low acidity of H-Y. Mo-S/H-Y also produced a much larger yield (11.9\%) of alkylbenzenes and a much lower BTX yield (37.3\%). Mo-S/ BZ(90:10) catalyst produced 53\% of BTX plus about 7\% of other alkylbenzenes, giving a total of $60 \%$ mono-aromatics. On the other hand, the yield of naphtha over the Mo-S/ H-Y catalyst reached $20.9 \%$, which was 3.6 times that achieved over the Mo-S/BZ (90:10) catalyst (5.8\%). Hence, the mesoporous Mo-S/ H-Y catalyst was not an active or selective hydrocracking catalyst compared to Mo-S/BZ (90:10) when tetralin was used as a model feed. As a partial conclusion the authors decided that because actual HDT LCO contains a significant fraction of large tri +-ring aromatic molecules, to increase the conversion of large molecules in the LCO and thereby to enhance the BTX yield from real feeds, a small amount of H-Y zeolite (5 or 10\%) can be useful. Results regarding this observation will be discussed in the real feed section.

\section{Effect of the metal and content}

Choi et al. [21] prepared Ni/H-Beta by wet impregnation of an aqueous solution of nickel (II) nitrate hexahydrate $\left(\mathrm{Ni}\left(\mathrm{NO}_{3}\right)_{2} \cdot 6 \mathrm{H}_{2} \mathrm{O}\right)$ on H-Beta $\left(\mathrm{SiO}_{2} / \mathrm{Al}_{2} \mathrm{O}_{3}=75\right)$ The Ni loading amount was $2 \mathrm{wt} . \%$. The main product was BTX with $41 \%$ maximum total yield obtained at $450{ }^{\circ} \mathrm{C}$ WHSV of $2 \mathrm{~h}^{-1}, 4 \mathrm{MPa}$, and $\mathrm{H}_{2}$ /tetralin mole ratio of 8 , Other products obtained in lesser amounts were non-aromatic hydrocarbons (HYD), $\mathrm{C}_{9+}$-alkylbenzenes ( $\left.\mathrm{C}_{9+} \mathrm{ALB}\right)$, and heavy aromatic compounds (HH: i.e. naphthalene derivatives) with total yields of $6.4,2.5$ and $5.5 \%$, respectively.

The same group [22] carried out a more detailing study by changing the nickel contents $(1,2,5$ and $10 \%)$ that were prepared by wet impregnation of an aqueous solution of $\mathrm{Ni}\left(\mathrm{NO}_{3}\right)_{2} \cdot 6 \mathrm{H}_{2} \mathrm{O}$ on $\mathrm{H}$-Beta with two different $\mathrm{SiO}_{2} / \mathrm{Al}_{2} \mathrm{O}_{3}$ ratios (38 or 75). They also prepared $\mathrm{NiSn} / \mathrm{H}$-Beta catalysts

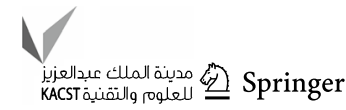


by a sequential wet impregnation method. The tin precursor solution, which was prepared by dissolving $\mathrm{SnCl}_{2} \cdot 2 \mathrm{H}_{2} \mathrm{O}$ in $1 \mathrm{M} \mathrm{HCl}$ solution, was first impregnated on $\mathrm{H}$-Beta followed by drying, then an aqueous solution of $\mathrm{Ni}\left(\mathrm{NO}_{3}\right)_{2} \cdot 6 \mathrm{H}_{2} \mathrm{O}$ was impregnated on the $\mathrm{Sn}$-impregnated catalyst. For comparison purposes, they also prepared a $\mathrm{Co}(3)-\mathrm{Mo}(8) / \mathrm{H}-\mathrm{Beta}$ catalyst by a wet impregnation method with metal precursors $\mathrm{Co}\left(\mathrm{NO}_{3}\right)_{2} \cdot 6 \mathrm{H}_{2} \mathrm{O}$ and $\left(\mathrm{NH}_{4}\right)_{6} \mathrm{Mo}_{7} \mathrm{O}_{24} \cdot 4 \mathrm{H}_{2} \mathrm{O}$. The highest BTX total yields of 46,48 , and $47 \%$ were obtained with $\mathrm{Ni}(5) \mathrm{Sn}(3) / \mathrm{H}-\mathrm{Beta}, \mathrm{Ni}(5) \mathrm{Sn}(5) / \mathrm{H}-\mathrm{Beta}$, and $\mathrm{Co}(3) \mathrm{Mo}(8) / \mathrm{H}-$ Beta, respectively, when reacting at the same experimental conditions: $450{ }^{\circ} \mathrm{C}$ WHSV of $2 \mathrm{~h}^{-1}, 4 \mathrm{MPa}$, and $\mathrm{H}_{2} /$ tetralin mole ratio of 8 . BTX were the main products of this reaction, some other products found in lesser quantities were light hydrocarbons (LP: 3, 5, and 8\%) $\mathrm{C}_{9+}$-alkylbenzenes $\left(\mathrm{C}_{9+} \mathrm{ALB}: 12,9\right.$, and $\left.12 \%\right)$, tetralin, and indane derivatives (TI: $1,0.7$, and $0.6 \%$ ), and heavy hydrocarbons i.e. naphthalene derivatives ((HH: 1, 6, 4, and 1.6\%) for the same catalyst at the same experimental conditions. The effect of the different metal and content was almost negligible.

Upare et al. [23] prepared cobalt promoted $\mathrm{Mo} / \mathrm{H}-$ Beta catalysts using Beta $(\beta)$ zeolite with different $\mathrm{SiO}_{2} /$ $\mathrm{Al}_{2} \mathrm{O}_{3}$ mole ratios of $25(\beta 1), 75(\beta 2), 150(\beta 3)$ and mordenite (MOR) with $\mathrm{SiO}_{2} / \mathrm{Al}_{2} \mathrm{O}_{3}$ mole ratio of 20 . The molybdenum catalysts were prepared by incipient wetness impregnation method using appropriate concentrations of $\left(\mathrm{NH}_{4}\right)_{6} \mathrm{Mo}_{7} \mathrm{O}_{24} \cdot 4 \mathrm{H}_{2} \mathrm{O}$. The cobalt promoted (3.3\%) catalysts were prepared by co-impregnation of $\mathrm{Co}\left(\mathrm{NO}_{3}\right)_{2} \cdot 6 \mathrm{H}_{2} \mathrm{O}$ and $\left(\mathrm{NH}_{4}\right)_{6} \mathrm{Mo}_{7} \mathrm{O}_{24} \cdot 4 \mathrm{H}_{2} \mathrm{O}$ on Beta zeolite supports. The CoMo/ H-Beta-1 catalyst gave the highest BTX yield of $42 \%$ followed by the $\mathrm{Mo} / \mathrm{H}-\mathrm{Beta}-1$ with $34 \%$ and $\mathrm{CoMo} / \mathrm{H}$-Beta-2 with $33 \%$ at $380{ }^{\circ} \mathrm{C}, 8 \mathrm{MPa}, 1.6 \mathrm{~h}^{-1} \mathrm{LHSV}$, and $\mathrm{H}_{2}$ flow rate of $100 \mathrm{~mL} / \mathrm{min}$, being present in the highest conversion. Other compounds present in lesser amounts were $\mathrm{C}_{9+}$-alkylbenzenes $\left(\mathrm{C}_{9+} \mathrm{ALB}\right)$ being 7,10 , and $10 \%$ in the same order. In this case, not only the bimetallic presence was superior in the BTX production than the monometallic catalyst [12, 14], but also the support type (Beta-1 versus Beta-2) mattered, having the former higher Brønsted, Lewis, and total acidities.

Continuing with their study, Upare et al. [24] synthesized the catalysts CoMo (0.5)/H-Beta, CoMo (1.0)/H-Beta, and CoMo (1.5)/H-Beta where the number in parentheses is the cobalt/molybdenum ratio [23] while maintaining the same $\mathrm{H}$-Beta support $(\mathrm{Si} / \mathrm{Al}=25)$. By testing these catalysts for the tetralin hydrocracking at $370{ }^{\circ} \mathrm{C}, 8 \mathrm{MPa}, 1.6 \mathrm{~h}^{-1} \mathrm{LHSV}$, and $\mathrm{H}_{2}$ flow rate of $100 \mathrm{~mL} / \mathrm{min}$, they obtained BTX total yields of 42,36 and $33 \%$, in the order: CoMo (0.5)/H-Beta, CoMo (1.0)/H-Beta, and CoMo (1.5)/H-Beta, respectively. $\mathrm{C}_{4}-\mathrm{C}_{7}$ paraffins (LP: 8, 7.4 and 6\%), $\mathrm{C}_{9+}$-alkylbenzenes $\left(\mathrm{C}_{9+} \mathrm{ALB}\right.$ : 6.6, 6.8 and $\left.6.7 \%\right)$ were also formed in the same order. This result obviously followed the findings described by Charisiou et al. [14], that the bimetallic ration was also important in the catalytic behavior.

Shin et al. [25] prepared catalysts with various metallic components including $\mathrm{Ni}, \mathrm{NiSn}, \mathrm{CoMo}, \mathrm{NiMo}$, and $\mathrm{NiW}$ supported on $\mathrm{H}$-Beta $\left(\mathrm{SiO}_{2} / \mathrm{Al}_{2} \mathrm{O}_{3}=38.0\right.$ or 75.0$)$ and hybrid zeolites by wet impregnation. The hybrid zeolites were prepared by physical mixing of $\mathrm{H}-\mathrm{Beta}$ and HZSM-5 $\left(\mathrm{SiO}_{2} /\right.$ $\mathrm{Al}_{2} \mathrm{O}_{3}=30$ ) with different HZSM-5 contents and are denoted as $\mathrm{BZ}(\mathrm{x})$ hereafter, where $\mathrm{x}$ indicates the HZSM-5 content in \%. Zeolite-supported $\mathrm{Ni}$ and $\mathrm{NiSn}$ catalysts with $\mathrm{Ni}$ and Sn contents of 5 and $3 \%$, respectively, were prepared with $\mathrm{Ni}\left(\mathrm{NO}_{3}\right)_{2} \cdot 6 \mathrm{H}_{2} \mathrm{O}$ and $\mathrm{SnCl}_{2} \cdot 2 \mathrm{H}_{2} \mathrm{O}$ as the metal precursors. The NiSn was supported on BZ(x) $(x=10,20$, and 38.5) to study the effect of HZSM-5 content in the hybrid zeolites on the tetralin hydrocracking. The sulfide-metal catalysts, $\mathrm{CoMo}(\mathrm{Co}=3 \%$ and $\mathrm{Mo}=8 \%), \mathrm{NiMo}(\mathrm{Ni}=3 \%$ and $\mathrm{Mo}=8 \%)$, and $\mathrm{NiW}(\mathrm{Ni}=3.5 \%$ and $\mathrm{W}=24 \%)$ were supported on $\mathrm{H}-\mathrm{Beta}$ and $\mathrm{BZ}(\mathrm{x})$ by wet impregnation using $\mathrm{Co}\left(\mathrm{NO}_{3}\right)_{2} \cdot 6 \mathrm{H}_{2} \mathrm{O},\left(\mathrm{Ni}\left(\mathrm{NO}_{3}\right)_{2} \cdot 6 \mathrm{H}_{2} \mathrm{O}\right),\left(\mathrm{NH}_{4}\right)_{6} \mathrm{Mo}_{7} \mathrm{O}_{24} \cdot 4 \mathrm{H}_{2} \mathrm{O}$, and $\left(\mathrm{NH}_{4}\right)_{6} \mathrm{H}_{2} \mathrm{~W}_{12} \mathrm{O}_{40} \cdot 5 \mathrm{H}_{2} \mathrm{O}$. All the tested catalysts at $425{ }^{\circ} \mathrm{C}, 4 \mathrm{MPa}$, and WHSV of $2 \mathrm{~h}^{-1}$ produced a rather high total BTX yield between 44 and $53 \%$, providing the best results the NiSn/H-Beta ZSM-5 (90/10) with 52\% and NiMo/H-Beta ZSM-5 (90/10) with 53\%. Secondary products were naphtha like compounds (HYD) in yields between 1 and $11 \%$, being for NiSn/H-Beta ZSM-5 (90/10) $7.4 \%$ and NiMo/H-Beta ZSM-5 (90/10) 6\%. Other important secondary products were $\mathrm{C}_{9+} \mathrm{ALBs}$ in amounts between 2 and $16 \%$. NiSn/H-Beta ZSM-5 (90/10) with 6\% and NiMo/H-Beta ZSM-5 (90/10) with 7\%. Other products found were indene (TI) and naphthalene derivatives (HH) in lesser amounts. It is inferred that the NiMo/BZ catalyst (10) is a good candidate for use in the selective hydroconversion of polyaromatic hydrocarbons (PAH) to produce high-value BTX, as its metallic, acidic, and structural properties are well balanced.

\section{Partial conclusion}

In this work, a relationship between the catalyst characteristics and the BTX total yield was the main task. Figure 2 shows the most important results regarding BTX total yields [3, 20-25]. A total BTX yield higher than $53 \%$ was never attained using a hydrocracking catalyst of any type, due to the inevitable gas formation and other $\mathrm{C}_{9+}$-alkylbenzenes formed. The theoretical $63 \mathrm{wt} . \%$ BTX conversion was never reached. As it can be seen from the results, BTX was never formed solely but accompanied by hydrogenated hydrocarbons (naphthene compounds) and other alkylbenzenes. The only correlation available in this case, was the relation between the metal content/BET 
Fig. 2 Main results for the effect of the catalyst in the BTX total yield from tetralin hydrocracking

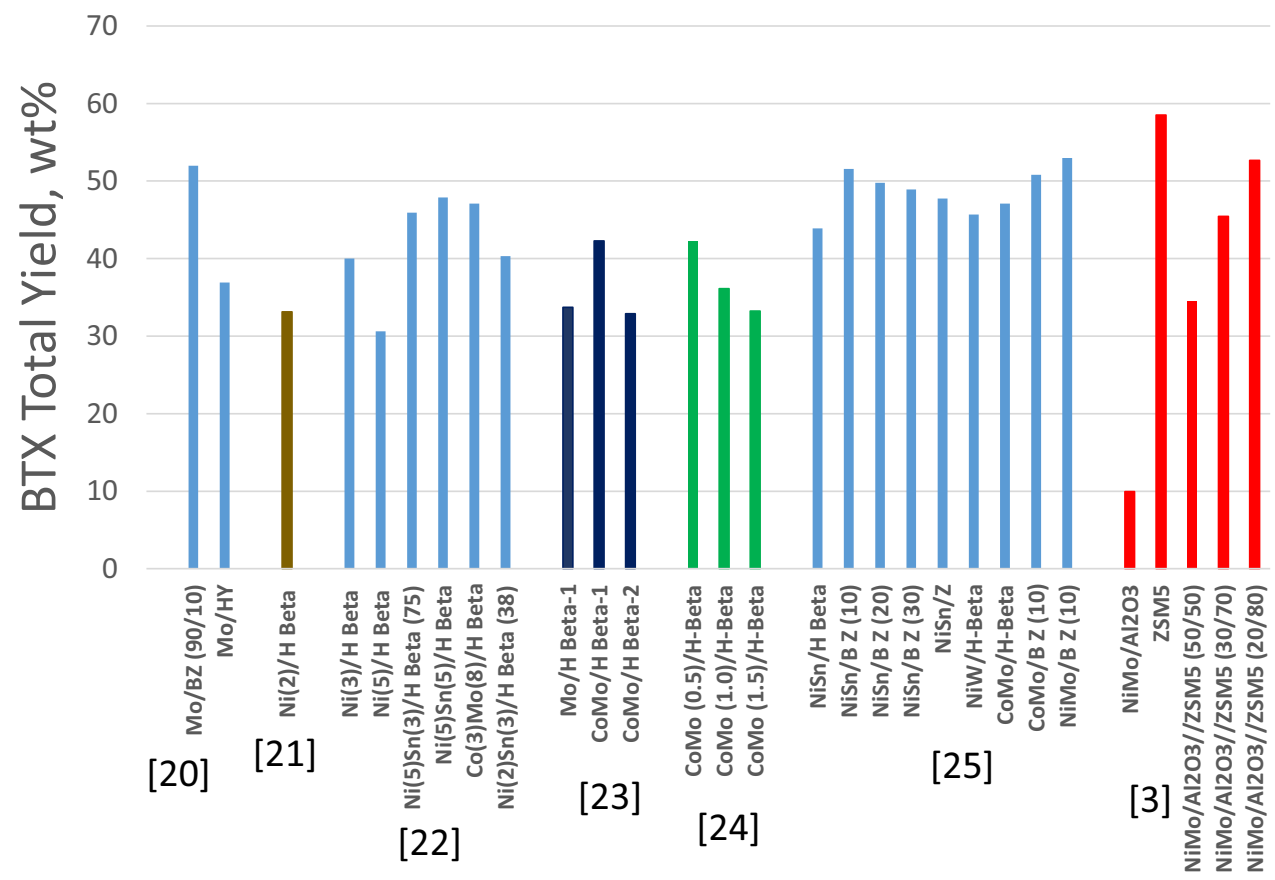

surface ratio versus the BTX total yield (wt.\%) (Fig. 3), which indicates that the density of metal sites is an important factor in the BTX yield. On the other hand, it seems logical that a better dispersion of the metals contributes to the accessibility of the molecules to the catalytic sites and therefore, increased the selectivity of the reaction [12]. According to Fig. 4, the best catalysts for BTX production were those conformed by $\mathrm{Ni}$, CoMo, NiMo, or NiSn over zeolite H-Beta. Adding a 10 wt.\% of ZSM-5 to the H-Beta, the BTX formation can be improved [3, 20, 25]. After dividing the most important BTX yields in groups (Fig. 4) it is noteworthy that the first group, which covers BTX yields from 40-45 wt.\%, is not that different from the best performance group (50-53\%) of catalysts. It is evident that a balance between metal and acid function are needed to obtain a higher yield and this does not depend on a specific metal or support.

\section{BTX production from naphthalene and naphthalene derivatives}

A summary of the characteristics of the catalyst prepared for BTX production from naphthalene derivatives is shown in Table 2. The order of the references depended on the time of publication.

\section{Effect of the acidity and support structure}

Arribas and Martínez [26] prepared Pt/USY catalysts by impregnating the USY zeolites with a $0.2 \mathrm{~N} \mathrm{HCl}$ solution containing the required amount of hexachloroplatinic acid to obtain a nominal concentration of $1 \% \mathrm{Pt}$ in the final catalyst and used 1-methylnaphthalene (1-MN) as a representative molecule of the diaromatics present in distillate fuels. Five different USY zeolites were prepared and used as supports: commercial USY-1 (CBV500, $\mathrm{NH}_{4}{ }^{+}$form); USY-3
Fig. 3 Effect of the metal content/BET surface ratio on the BTX total yield from tetralin

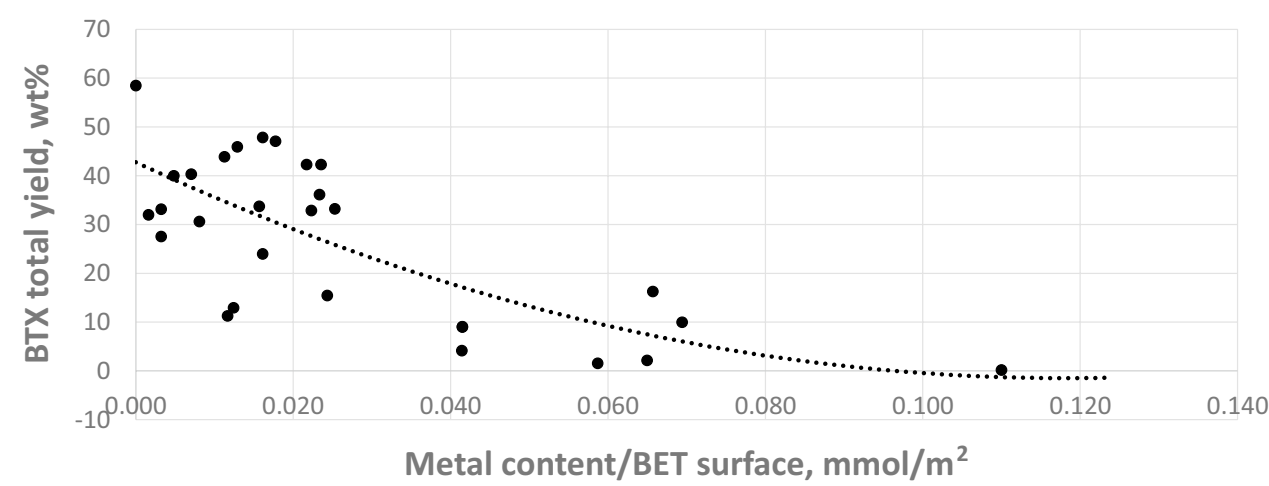

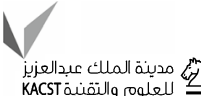
Springer 
Fig. 4 Worst to the best catalyst for tetralin hydrocracking for BTX production

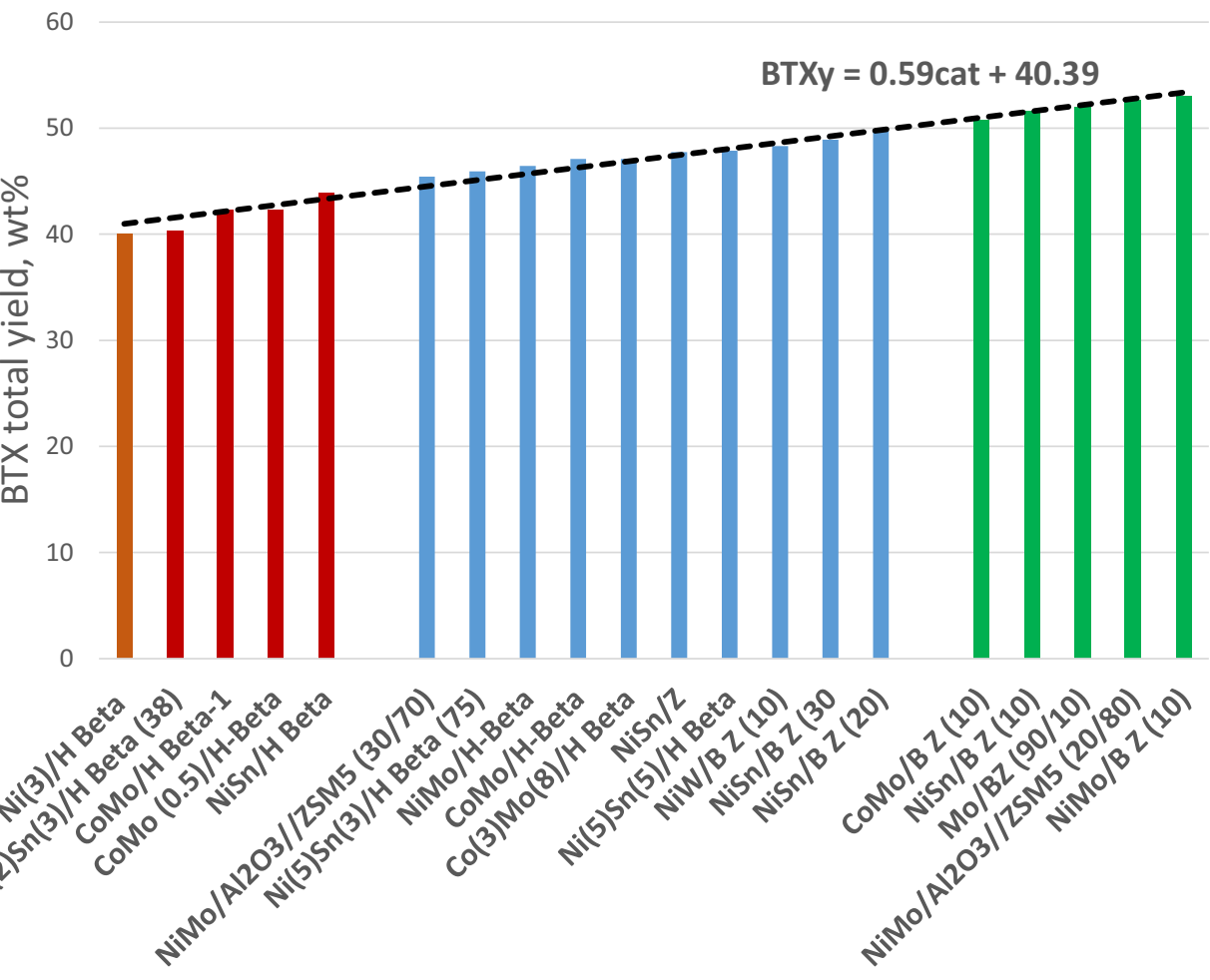

(CBV712, $\mathrm{NH}_{4}{ }^{+}$form) and USY-5 (CBV760, $\mathrm{H}^{+}$form). The protonic forms of USY-1 and USY-3 were produced by calcination $\left(500^{\circ} \mathrm{C}, 3 \mathrm{~h}\right)$. USY-2 and USY-4 were prepared by $\mathrm{NH}_{4}{ }^{+}$exchange from a commercial NaY sample, followed by washing until the absence of chlorine, drying at $100{ }^{\circ} \mathrm{C}$ overnight, and steamed at 600 and $700{ }^{\circ} \mathrm{C}$ for 3 and $5 \mathrm{~h}$, respectively. Finally, the sample USY-4 was further steamed at $760{ }^{\circ} \mathrm{C}$ for $8 \mathrm{~h}$. Ammonium exchange treatments were carried out with a $2.5 \mathrm{~N}$ aqueous solution of $\mathrm{NH}_{4} \mathrm{Cl}$ at $80{ }^{\circ} \mathrm{C}$ for $2 \mathrm{~h}$ under agitation. Using a fixed bed reactor at the following experimental conditions: $325-355^{\circ} \mathrm{C}, \mathrm{WHSV}=2.0 \mathrm{~h}^{-1}$, total pressure $=4 \mathrm{MPa}, \mathrm{H}_{2} / \mathrm{HC}$ of $30 \mathrm{~mol} / \mathrm{mol}$, the main products were methyltetralin and dimethylindane with total yields between 41 and $81 \%$, following by decalin derivatives (D, 8 and 28\%). The total BTX conversion was only between 6 and $16 \%$. These materials presented the highest BET surface and Brønsted/Lewis ratio. According to the authors, both the framework and extraframework composition of the USY zeolite influenced the acidic and catalytic properties of the Pt/USY catalysts, particularly for those reactions requiring the presence of Brønsted acid sites, i.e. isomerization, ring-opening, cracking, and dealkylation. In general, noble metal catalysts are not preferred for hydrocracking reactions due to their sensibility to sulfur and nitrogen compounds presented in real feeds [2, 10, 14].

Kim et al. [27] studied the hydrocracking of naphthalene to $\mathrm{BTX}$ by a $\mathrm{Ni}_{2} \mathrm{P} /$ zeolite supported catalyst. The supports used in this study were zeolite Beta, USY, ZSM-5, and $\mathrm{SiO}_{2}$.
Supported $\mathrm{Ni}_{2} \mathrm{P}$ catalysts were prepared by incipient wetness impregnation of aqueous metal phosphate precursors, followed by temperature-programmed reduction (TPR) in flowing hydrogen. The initial $\mathrm{Ni} / \mathrm{P}$ ratio in the precursors was fixed at 0.5 . The amount of Ni loading was fixed at $1.5 \mathrm{mmol} / \mathrm{g}$ of support. The supported nickel phosphate precursor was prepared by incipient wetness impregnation of a solution of $\mathrm{Ni}\left(\mathrm{NO}_{3}\right)_{2} 6 \mathrm{H}_{2} \mathrm{O}$ and $\left(\mathrm{NH}_{4}\right)_{2} \mathrm{HPO}_{4}$, followed by drying and calcination. The $\mathrm{Ni}_{2} \mathrm{P} / \mathrm{SiO}_{2}$ catalyst was found active only for the hydrogenation of naphthalene, producing tetralin and decalin at 3.0 $\mathrm{MPa}$ and $400{ }^{\circ} \mathrm{C}$. BTX formation was provided for the $\mathrm{Ni}_{2} \mathrm{P} / \mathrm{Beta}$, demonstrating the bifunctional catalytic activity which was attributed to its unique nature of moderate acidity and porosity combined with hydrogenation activity of well-dispersed $\mathrm{Ni}_{2} \mathrm{P}$ phase [12]. The authors claimed naphthalene conversions between 90-99\% and BTX yield up to $94.4 \%$ for the $\mathrm{Ni}_{2}$ P/Beta zeolite, however, due to the shortness of the communication, it was required to add some assumptions for attaining a more realistic value: (1) Even if the naphthalene conversion was $99 \%$, the mass balance will give a liquid yield up to $65 \%$ maximum. (2) Usually, not only BTX was formed but other $\mathrm{C}_{9+}$-alkyl-aromatics, therefore the BTX yield of $61 \%$ must be taken with caution as the following publications from the same authors probed to be [28-30].

To obtain bi-functional catalysts with high activity for the selective hydrocracking of 1-methylnaphthalene to BTX, Kim et al. [28] prepared a NiW-supported catalyst 


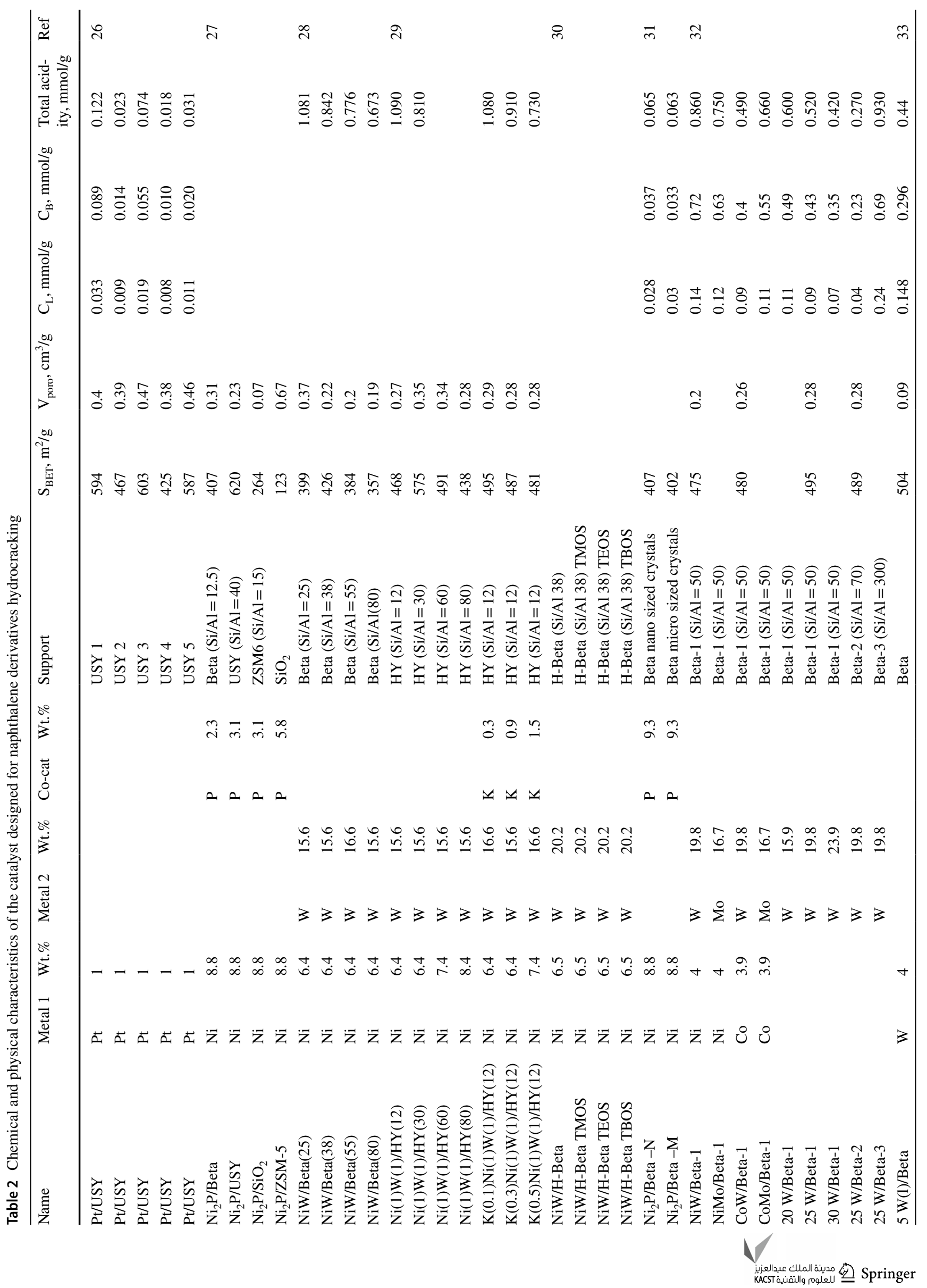




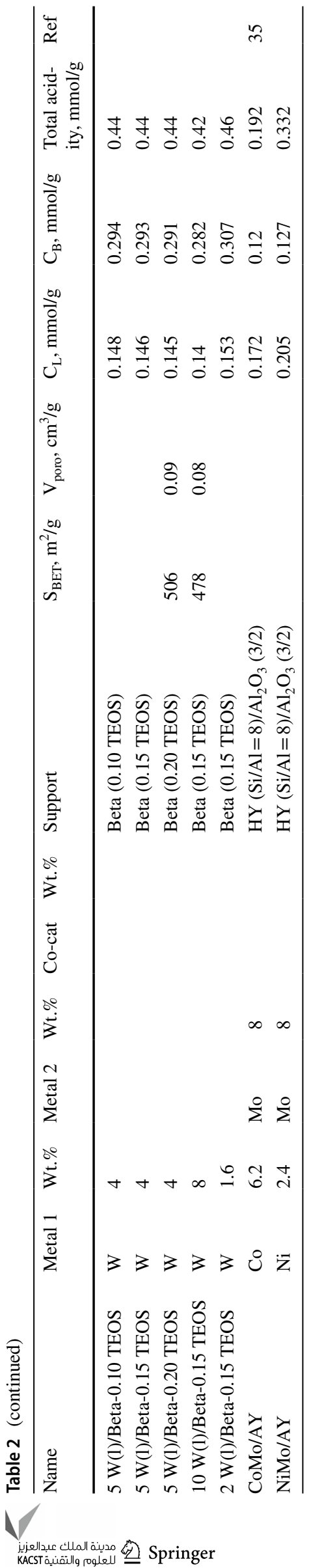

with different acidity. The catalysts were synthesized from $\mathrm{Ni}\left(\left(\mathrm{NO}_{3}\right)_{2} \cdot 6 \mathrm{H}_{2} \mathrm{O},\left(\mathrm{NH}_{4}\right)_{6} \mathrm{H}_{2} \mathrm{~W}_{12} \mathrm{O}_{40} \cdot \mathrm{H}_{2} \mathrm{O}\right.$, and dealuminated Beta zeolites $\left(\mathrm{SiO}_{2} / \mathrm{Al}_{2} \mathrm{O}_{3}\right.$ mole ratio $=25,38,55$, and 80 ) by wet impregnation method. $1 \mathrm{~g}$ of the catalyst with nickel (Ni, $1 \mathrm{mmol}, 6.4 \%)$ and tungsten $(\mathrm{W}, 1 \mathrm{mmol}$, 15.6 wt.\%) on $\mathrm{H}$-Beta was sulfided in $\mathrm{H}_{2} \mathrm{~S}(10 \%) / \mathrm{H}_{2}$ flow at $350{ }^{\circ} \mathrm{C}$ for $3 \mathrm{~h}$. The sulfided catalyst was loaded in the fixed-bed reactor and pretreated in $\mathrm{H}_{2}$ flow at $400{ }^{\circ} \mathrm{C}$ and atmospheric pressure for $8 \mathrm{~h}$. After, the pressure increased to $5 \mathrm{MPa}$ and both the liquid feed of 1-methylnaphthalene $\left(0.037 \mathrm{~cm}^{3} / \mathrm{min}\right)$ and $\mathrm{H}_{2}\left(175 \mathrm{~cm}^{3} / \mathrm{min}\right)$ was passed through the catalyst bed. The catalysts with a $\mathrm{SiO}_{2} / \mathrm{Al}_{2} \mathrm{O}_{3}$ mole ratio of $25,38,55$, and 80 showed an acidity of $1.081,0.842$, 0.776 , and $0.673 \mathrm{mmol} \mathrm{NH}_{3} / \mathrm{g}$, respectively. A fair amount of hydrocracking gases was formed with the more acidic catalysis (34-46\%). Likewise, catalysts with an acidity of $1.081,0.842$, and $0.776 \mathrm{mmol} \mathrm{NH}_{3} / \mathrm{g}$ offered BTX yields of 33,39 , and $45 \%$, respectively. The catalyst with an acidity of $0.673 \mathrm{mmol} \mathrm{NH}_{3} / \mathrm{g}$ showed a BTX yield of only $9 \%$. Other compounds were formed in lesser amounts: light (LP: 2-7\%) and cyclic alkanes (HYD: 1-9\%), $\mathrm{C}_{9+}$-alkylbenzenes $\left(\mathrm{C}_{9+} \mathrm{ALB}: 4-10 \%\right)$, and other heavy hydrocarbons (HH: 4-12\%). The obtained results indicated that the acidity of the catalyst has an important role as active sites for the selective ring-opening of 1-methylnaphthalene [3,12], however, acidity is not directly proportional to the BTX yield.

It is known that the acidity of the catalyst is important for the hydrocracking of multi-ring aromatics $[3,12]$, therefore, to obtain BTX, Lee et al. [29] submitted 1-methylnaphthalene to a selective ring-opening reaction over $\mathrm{KNiW} / \mathrm{HY}$ catalysts with different acidity in a fixed-bed flow reactor. The catalysts were prepared by loading $\mathrm{HY}$ zeolites $\left(\mathrm{SiO}_{2} /\right.$ $\mathrm{Al}_{2} \mathrm{O}_{3}$ mole ratio of 12 and 30) with $1 \mathrm{mmol} / \mathrm{g}$ of nickel (Ni: $6.4 \%$ ), $1 \mathrm{mmol} / \mathrm{g}$ of tungsten (W: $15.6 \%$ ) and $0.1,0.3$, and $0.5 \mathrm{mmol} / \mathrm{g}$ of potassium (K: $0.3,0.9$ and $1.5 \%$ ) metals via a wet impregnation method. Thus, the hydrogenform zeolite was impregnated with an aqueous solution of $\mathrm{Ni}\left(\mathrm{NO}_{3}\right)_{2} \cdot 6 \mathrm{H}_{2} \mathrm{O},\left(\mathrm{NH}_{4}\right)_{6} \mathrm{H}_{2} \mathrm{~W}_{12} \mathrm{O}_{40} \mathrm{H}_{2} \mathrm{O}$, and $\mathrm{KNO}_{3}$, and the water was eliminated from the material, dried, and calcinated. The catalyst was sulfided in $\mathrm{H}_{2} \mathrm{~S}(10 \%) / \mathrm{H}_{2}$ flow at $350{ }^{\circ} \mathrm{C}$ for $3 \mathrm{~h}$. Before the reaction test, $1 \mathrm{~g}$ of catalyst was reduced using $\mathrm{H}_{2}$ flow under atmospheric pressure at $400{ }^{\circ} \mathrm{C}$ for $8 \mathrm{~h}$. The activity test was carried out using 1-methylnaphthalene $\left(0.037 \mathrm{~cm}^{3} / \mathrm{min}\right)$ and $\mathrm{H}_{2}\left(\mathrm{~cm}^{3} / \mathrm{min}\right)$ at $5 \mathrm{MPa}$ and $400{ }^{\circ} \mathrm{C}$. The sequence of the acidity was $\mathrm{Ni}(1) \mathrm{W}(1) /$ $\mathrm{HY}(12)>\mathrm{K}(0.1) \mathrm{Ni}(1) \mathrm{W}(1) / \mathrm{HY}(12)>\mathrm{K}(0.3) \mathrm{Ni}(1) \mathrm{W}(1) /$ $\mathrm{HY}(12)>\mathrm{Ni}(1) \mathrm{W}(1) / \mathrm{HY}(30)>\mathrm{K}(0.5) \mathrm{Ni}(1) \mathrm{W}(1) / \mathrm{HY}(12)$. The acidity decreased with the increase of $\mathrm{SiO}_{2} / \mathrm{Al}_{2} \mathrm{O}_{3}$ mole ratio of the $\mathrm{HY}$ zeolite and the $\mathrm{K}$ in the catalyst. The catalysts with a potassium content of $0.1,0.3$, and $0.5 \mathrm{mmol} / \mathrm{g}$ $(0.3,0.9$ and $1.5 \%)$ showed a BTX selectivity $21.4,24$, and $8 \%$ providing a BTX total yield of 21,23 , and $7 \%$, respectively. In this case, other hydrocarbons were produced, in 
similar amounts, like light (LP: 16-19\%) and cyclic alkanes (HYD: 10-27\%), $\mathrm{C}_{9+}$-alkylbenzenes ( $\mathrm{C}_{9+}$ ALB: 4-17\%), and other heavy hydrocarbons (HH: 5-14\%). The addition of $\mathrm{K}$ to the NiW/HY catalyst improved the catalytic activity for the selective ring-opening of 1-methylnaphthalene due to the optimization of catalyst acidity by the electronic surface modification.

Lee et al. [30] hydrocracked 1-MN using NiW/silylated Beta zeolites. The bifunctional catalysts were prepared as follows. $2 \mathrm{~g}$ of $\mathrm{H}$-Beta zeolite, which was obtained by calcination of its $\mathrm{NH}_{4}{ }^{+}$form with $\mathrm{SiO}_{2} / \mathrm{Al}_{2} \mathrm{O}_{3}$ mole ratio of 38 . The silylation was carried out by dissolving the silylation agent (TMOS, TEOS or TBOS) in $50 \mathrm{~mL}$ of hexane heated at $70{ }^{\circ} \mathrm{C}$, in the amount required to obtain a loading of $4.0 \% \mathrm{SiO}_{2}$. After $1 \mathrm{~h}$ of reaction, the hexane was eliminated by vacuum, and the solid product was dried and calcined. The H-Beta and the three silylated Beta zeolites were co-impregnated with an aqueous solution of $\mathrm{Ni}\left(\mathrm{NO}_{3}\right)_{2} \cdot 6 \mathrm{H}_{2} \mathrm{O}$ and $\left(\mathrm{NH}_{4}\right)_{6} \mathrm{H}_{2} \mathrm{~W}_{12} \mathrm{O}_{40} \cdot \mathrm{xH}_{2} \mathrm{O}$ in the amount required to load 1 and $1.1 \mathrm{mmol}$ of $\mathrm{Ni}$ and $\mathrm{W}$, respectively, per $1 \mathrm{~g}$ of zeolite; subsequently, the water was eliminated by vacuum, and the remaining solid was dried and calcined. In this case, the authors did not define the amount of BTX produced but the amount of ring-opening at $380{ }^{\circ} \mathrm{C}, 6.0 \mathrm{MPa}$, and $0.5 \mathrm{~h}^{-1}$ LHSV in a continuous-flow reactor. The ring-opening of 1-methyl naphthalene will produce a series of alkyl-benzenes or mono-aromatic compounds among them BTX hydrocarbons form part. Therefore, the best catalyst for RO followed the order: NiW/H-Beta-TBOS $(73 \%)>\mathrm{NiW} / \mathrm{H}-$ Beta-TEOS $(68 \%)>$ NiW/H-Beta $(62 \%)>$ NiW/H-BetaTMOS (61\%). The BTX yield can be estimated by their previous works [27-29] and considered for comparison purposes to be $20 \%$ or lower. The description of other subproducts was not given in this case.

Kim et al. [31] studied the effect of the support on the catalytic properties of $\mathrm{Ni}_{2} \mathrm{P} / \mathrm{H}$-Beta nano and mesoporous catalysts on the hydrocracking of 1-MN. The supports used in this study were two kinds of Beta zeolite with different crystal sizes, namely: nano-sized $(\beta-\mathrm{N})$ and micrometersized $(\beta-\mathrm{M})$, which were loaded with $1.5 \mathrm{mmol}$ of $\mathrm{Ni} / \mathrm{g}$ of support and mole ratio $\mathrm{P} / \mathrm{Ni}=2$ by incipient wetness impregnation using an aqueous solution of $\mathrm{Ni}\left(\mathrm{NO}_{3}\right)_{2} 6 \mathrm{H}_{2} \mathrm{O}$ and $\left(\mathrm{NH}_{4}\right)_{2} \mathrm{HPO}_{4}$, and followed by drying and calcination. Finally, the obtained materials were reduced and passivated using $\mathrm{H}_{2}$ and $0.1 \% \mathrm{O}_{2} / \mathrm{He}$, respectively, under specific conditions. The product distribution after hydrocracking 1-MN at $380{ }^{\circ} \mathrm{C}, 6.0 \mathrm{MPa}$, and LHSV of $0.5 \mathrm{~h}^{-1}$. Ni $\mathrm{N}_{2} \mathrm{P} /$ Beta-N provided a higher total BTX production than $\mathrm{Ni}_{2} \mathrm{P} /$ Beta-M. (53 vs. $49 \%$ ). Due to the good BTX target performance, these catalysts produced an array of other subproducts in lesser amounts.

\section{Studies using bifunctional catalysts}

Wu et al. [32] studied the selective hydrocracking of 1-methylnaphthalene to BTX using several sulfided transitions metals supported on H-Beta catalysts (Metals $=\mathrm{NiMo}$, $\mathrm{NiW}, \mathrm{CoMo}, \mathrm{CoW}, \mathrm{Mo}, \mathrm{W}$ ) in a fixed-bed reactor at $420{ }^{\circ} \mathrm{C}$ and $6 \mathrm{MPa}$. Thus, $\mathrm{Na}^{+}$form of Beta zeolite $\left(\mathrm{SiO}_{2} / \mathrm{Al}_{2} \mathrm{O}_{3}\right.$ ratio $=50$ (Beta-1), 70 (Beta-2), and 30 (Beta-3)) was synthesized from silica gel, sodium hydroxide, and sodium aluminate according to the method reported in the literature. After, the synthesized zeolites were ion-exchanged two times with an aqueous solution of $\mathrm{NH}_{4} \mathrm{NO}_{3}$ to obtain the $\mathrm{H}^{+}$ form of Beta zeolite. The catalysts were synthesized by the pore volume impregnation method. Beta zeolite supports were co-impregnated with an aqueous solution of nickel (or cobalt) nitrate, or ammonium molybdate (or tungsten) to prepare NiMo/Beta-1 (or CoMo/Beta-1, NiW/Beta-1, W/Beta1, Mo/Beta-1, W/Beta-2, W/Beta-3) catalyst. Later, these metal-impregnated zeolites were dried at room temperature for $12 \mathrm{~h}$, dried at $100{ }^{\circ} \mathrm{C}$ for $3 \mathrm{~h}$, and calcined at $550{ }^{\circ} \mathrm{C}$ for $3 \mathrm{~h}$ in air. To achieve an isothermal plug flow fixed-bed reactor, the reactor was loaded with a mixture of catalyst and quartz sand (20-40 mesh) with a mass ratio of 1:6. The catalyst was sulfided in a mixture of $1.5 \% \mathrm{CS}_{2}$ and cyclohexane and treated with $\mathrm{H}_{2}(50 \mathrm{~mL} / \mathrm{min})$ at room temperature and $6 \mathrm{MPa}$. Then, the temperature was increased to $240{ }^{\circ} \mathrm{C}$ $\left(7^{\circ} \mathrm{C} / \mathrm{min}\right)$, held at $240{ }^{\circ} \mathrm{C}$ for $3 \mathrm{~h}$, increased to $320^{\circ} \mathrm{C}\left(3{ }^{\circ} \mathrm{C} /\right.$ min), and held at $320^{\circ} \mathrm{C}$ for $3 \mathrm{~h}$. After, 1-methylnaphthalene ( 0.3 to $3 \mathrm{~mL} / \mathrm{h}$ ) was pumped into the reactor at a WHSV of $0.5-10 \mathrm{~h}^{-1}, \mathrm{H}_{2} /$ oil mole ratio of $30,6.0 \mathrm{MPa}$, and $420{ }^{\circ} \mathrm{C}$. The $25 \mathrm{~W} /$ Beta- 1 catalyst showed the best BTX yield (53\%) at $\mathrm{WHSV}=2 \mathrm{~h}^{-1}, \mathrm{H}_{2} /$ oil mole ratio of 30 , and $1.5 \mathrm{~g}$ of the mixture of catalyst and quartz sand. Conversion reached above $98 \%$ at WHSV below $1.4 \mathrm{~h}^{-1}$, however, the best BTX yields for all the catalysts were obtained between 1.7 and $2.5 \mathrm{~h}^{-1}$ of WHSV. At these conditions, the BTX selectivity decreased in the next order: $25 \mathrm{~W} /$ Beta-1 $(53 \%)>20 \mathrm{~W} /$ Beta-1, 30 W/Beta-1, 25 W/Beta-3, CoW/Beta-1> 25 W/ Beta- $2>$ CoMo/Beta-1 $>$ NiMo/Beta- $1>$ NiW/Beta-1, Mo/ Beta-1 (15\%). The $20 \mathrm{~W} /$ Beta-1 catalyst achieved a higher BTX yield (51\%) than the $25 \mathrm{~W} /$ Beta-1 $(45 \%)$ when the WHSV was lower than $2 \mathrm{~h}^{-1}$. As the BTX selectivity decreased, more hydrogenated products were obtained, then, the authors concluded that the hydrogenation activity of the catalysts was affected both by the metallic species and their content as well as by the acidity of the Beta support. A strong acidity increased the interaction between the acid centers and the metallic centers, decreasing the hydrogenation activity of the catalysts.

Wu et al. [33] studied in detail the hydrocracking catalysis for BTX production from naphthalene type compounds. To make the catalysis manufacture cheaper, it was prepared

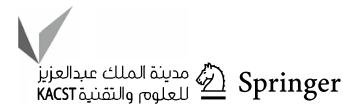


via the $\mathrm{WO}_{2}\left(\mathrm{C}_{6} \mathrm{H}_{6} \mathrm{NO}\right)_{2}$ complex, following the next procedure: $15 \mathrm{~mL}$ methanol and $0.4 \mathrm{~g} 2$-methoxypyridine were added to a solution of $0.3 \mathrm{~g}$ tungsten hexachloride in $15 \mathrm{~mL}$ of acetonitrile and then stirring at room temperature for $15 \mathrm{~min}$. The resultant solution was sealed in a Teflon-lined steel autoclave and heated in an oven at $150{ }^{\circ} \mathrm{C}$ for $20 \mathrm{~h}$. The red complex was isolated from the product solution by extraction with diethyl ether followed by the removal of the solvent. Regarding the support, Beta zeolite was synthesized by the stream-assisted crystallization method using silica, $\mathrm{NaAlO}_{2}$ and $\mathrm{NaOH}$ as silicon, aluminum, and alkali source, respectively. The obtained zeolite was first modified to its $\mathrm{H}^{+}$form via ion-exchange with $\mathrm{NH}_{4} \mathrm{NO}_{3}$ solution and then treated with the required amount of tetraethoxysilane (TEOS) in hexane. This mixture was stirred at room temperature for $5 \mathrm{~h}$, dried and calcined. The modified zeolites were labeled Beta- $x$, where $x=0.10,0.15$, and $0.20 \mathrm{~mL}$ of TEOS/g of zeolite. In this line, the tungsten-based catalysts were synthesized by the incipient wetness impregnation method using the tungsten complex and the modified zeolites prepared previously. The impregnated zeolite was dried both at room temperature and $100{ }^{\circ} \mathrm{C}$, and calcined. The catalysts were named as $y \mathrm{~W}(1) / \operatorname{Beta}-x$, where $y=2,5$, and $10 \mathrm{wt} . \%$. of tungsten. In the same way, a blank catalyst (W/ Beta) was prepared using an $\left(\mathrm{NH}_{4}\right)_{6} \mathrm{~W}_{7} \mathrm{O}_{24} \cdot 4 \mathrm{H}_{2} \mathrm{O}$ aqueous solution and the H-Beta zeolite unmodified. The experiments were carried out in a fixed bed reactor with WHSV referred to $1-\mathrm{MN}$, as $0.5-10 \mathrm{~h}^{-1}, \mathrm{H}_{2} / 1-\mathrm{MN}$ mole ratio equal to $30,6.0 \mathrm{MPa}$ pressure, and $420{ }^{\circ} \mathrm{C}$ temperature. Conversion reached almost $100 \%$ for some catalyst at WHSV below $1.7 \mathrm{~h}^{-1}$, however, the best BTX selectivity was obtained at WHSV between 1.5 and $8 \mathrm{~h}^{-1}$. For the comparison sake, the conversion considered would be when the best BTX yield was obtained. The total BTX yield ranged from 38 to $55 \%$, being the best the obtained with the $5 \mathrm{~W}(1) /$ Beta- $0.15(55 \%)$, and the worst with the $2 \mathrm{~W}(\mathrm{l}) /$ Beta-0.15 (38\%). When the BTX yields decreased the second kind of compounds produced were hydrogenated hydrocarbons (HYD: 9-13\%) and $\mathrm{C}_{9+}$-alkylbenzenes (( $\mathrm{C}_{9+} \mathrm{ALB}$ : 8-10\%).

Recently, Cao et al. [34] reported the hydrocracking of naphthalene over bi-functional NiMo and CoMo catalysts. These catalysts were prepared by incipient-wetness impregnation method using an aqueous solution of heptamolybdate tetrahydrate, cobalt-nitrate hexahydrate and nickel nitrate hexahydrate as $\mathrm{Mo}, \mathrm{Co}, \mathrm{Ni}$ sources, respectively, and an $\mathrm{HY}$ zeolite $(\mathrm{Si} / \mathrm{Al}=8)-\mathrm{Al}_{2} \mathrm{O}_{3}$ mixture with a ratio of 1.3:2 mass as support. First, the precursor of Mo was impregnated, then the precursor of $\mathrm{Ni}$ or $\mathrm{Co}$. The obtained solids were dried at $80{ }^{\circ} \mathrm{C}$ and calcined at $500{ }^{\circ} \mathrm{C}$. The catalysts have a mass percentage of 12,3 , and $3 \%$ to $\mathrm{MoO}_{3}, \mathrm{CoO}$, and $\mathrm{NiO}$, respectively. The hydrocracking of cyclohexane solution with $1 \%$ naphthalene was carried out in a continuous-flow reactor using $1 \mathrm{~g}$ catalyst at $6.0 \mathrm{MPa}$ and an $\mathrm{H}_{2} /$ oil ratio of 200 .
Previously, the catalyst was sulfided using a cyclohexane solution with 2.5 vol. $\% \mathrm{CS}_{2}$ at $370{ }^{\circ} \mathrm{C}$ for $3 \mathrm{~h}$. The CoMo catalyst showed a higher conversion of naphthalene to BTX than those of NiMo catalyst at $320-420{ }^{\circ} \mathrm{C}$. For both catalysts, the conversions of naphthalene increased with the increasing temperature from 320 to $360^{\circ} \mathrm{C}$. The best mole yields of BTX were 22 and $20 \%$ for the CoMo and NiMo catalysts, respectively, at $340{ }^{\circ} \mathrm{C}$. The aim of these authors was not to produce BTX but gasoline, then the BTX yields for this kind of feedstock were low.

\section{Partial conclusion}

Figure 5 shows a summary of the total BTX yield from naphthalene derivatives from the principal results [27-33]. The highest total BTX yield was 55\% using a hydrocracking catalyst composed of $5 \mathrm{~W}(1) /$ Beta- 0.15 (TEOS) [33] remarkably like the maximum yield attained when BTX was obtained from tetralin hydrocracking (53\%). The 65\% theoretical conversion was never reached because not only BTX can be obtained, but also some hydrogenated hydrocarbons and other higher molecular weight alkylbenzenes, besides, with these model molecules (naphthalene and naphthalene derivatives) more hydrogenation and isomerization reactions may compete with the hydrocracking process [12].

In this case, the only relationship attainable for these results were the Brønsted/Lewis ratio versus the BTX total yield (Fig. 6). It seemed that to reach the best hydrocracking performance a balance between Brønsted and Lewis sites is required. According to Wu et al. [33] after carrying out kinetic studies of the 1-methylnaphthalene hydrocracking, they found out that the strong acidity resulted in a strong interaction between acid centers and metal centers, which can decrease the hydrogenation activity of the catalyst. On the other hand, low acidity resulted in high hydrogenation activity (high hydrogenation reaction rates) but low selective-hydrogenation activity, meaning that hydrogenation of the first and second aromatic rings can occur without giving place to hydrocracking by consecutive hydrogenation reactions. Therefore, a moderate acidity showed the highest balance of hydrogenation and cracking activity to achieve the highest BTX yields. Another important point was that the hydrogenating capacity of the metal and their synergistic effect of the promoter when it is used seem to have not significant effect on the BTX total yield. The same authors found out that the hydrogenation rates from the different metals decreased in the following order: $\mathrm{NiW}>\mathrm{NiMo}>\mathrm{CoMo}>\mathrm{CoW}$, and these results were consistent with previous studies. Figure 7 shows from the worst to the best catalyst for the naphthalene derivatives hydrocracking. In this case also, after dividing the most important BTX yields in groups (Fig. 7) it was found that the slope is steeper between the first group that covers the catalysts that 
Fig. 5 Main results for the effect of the catalyst in the BTX total yield from naphthalene derivatives hydrocracking
70
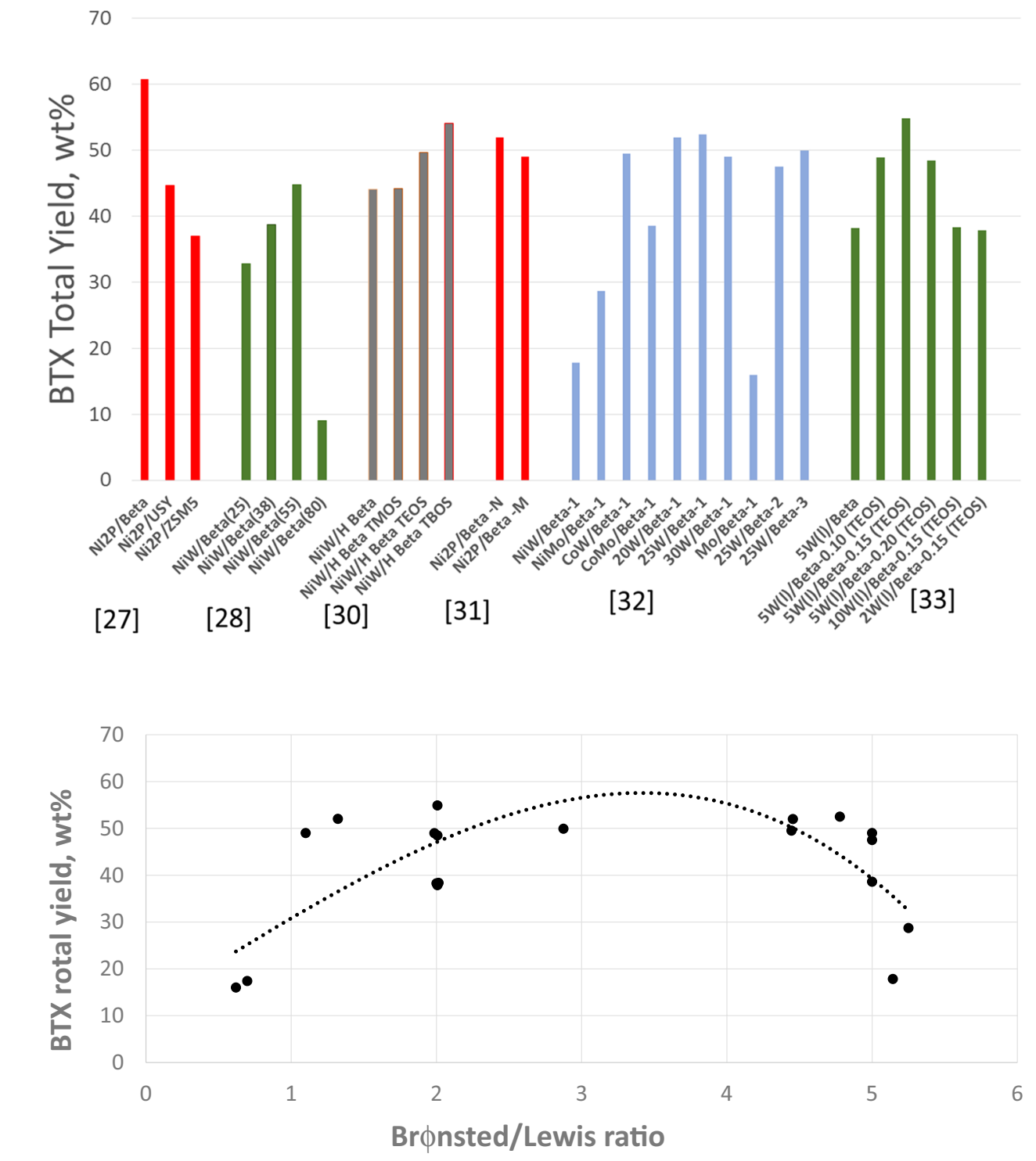

Fig. 6 Effect of the catalysts Brønsted/Lewis ration on the BTX total yield from naphthalene derivatives hydrocracking provided the worst BTX yields (35-40 wt.\%) and the best performance group (50-55\%) of catalysts.

\section{BTX production from real feeds}

\section{Effect of the catalyst on the BTX production}

A summary of the characteristics of the catalyst prepared for BTX production from real feeds is shown in Table 3. Many of the catalysts tested were derived from previous experiments with model mixtures. However, the major challenge is to convert a real feed like LCO into valuable benzene, toluene, and xylene hydrocarbons, mainly due to the presence of another type of compounds like sulfur, nitrogen, and heavy aromatic hydrocarbons which are going to test the hydrocracking process. Therefore, usually, the real feed requires to be hydrotreated (HDT) before the next HCK step is going to be taken [2, 4].

Upare et al. [23, 24] developed selective catalysis for the BTX production from pyrolysis fuel oil (PFO). The detailed catalysis synthesis was already described before [22]. In [23] the catalysis tested: Mo/H-Beta, CoMo/H-Beta and CoMo/MOR provided total BTX yields of 11, 20 and $5.3 \%$ at $370{ }^{\circ} \mathrm{C}, 8 \mathrm{MPa} \mathrm{H}_{2}, 1250 \mathrm{H}_{2} /$ feed (v/v), and LHSV of $1.6 \mathrm{~h}^{-1}$. Other products obtained were $\mathrm{C}_{9+}$-alkylbenzenes $\left(\mathrm{C}_{9+} \mathrm{ALB}\right)$ produced in the following amounts 5,13 , and $2 \%$ in the same order.

In the second effort [24], the catalyst tested $\mathrm{CoMo}(0.5) / \mathrm{H}$ Beta, CoMo(1.0)/H-Beta and $\operatorname{CoMo(1.5)/H-Beta~produced~a~}$ BTX total yield of 34, 35 and 32, respectively, in a fixed bed reactor at $370{ }^{\circ} \mathrm{C} ; 8 \mathrm{MPa} \mathrm{H}_{2}, 1250 \mathrm{H}_{2}$ /feed (v/v): and LHSV of: $0.2 \mathrm{~h}^{-1}$. Other products obtained were light paraffins 
Fig. 7 Worst to the best catalyst for naphthalene derivatives hydrocracking for BTX production

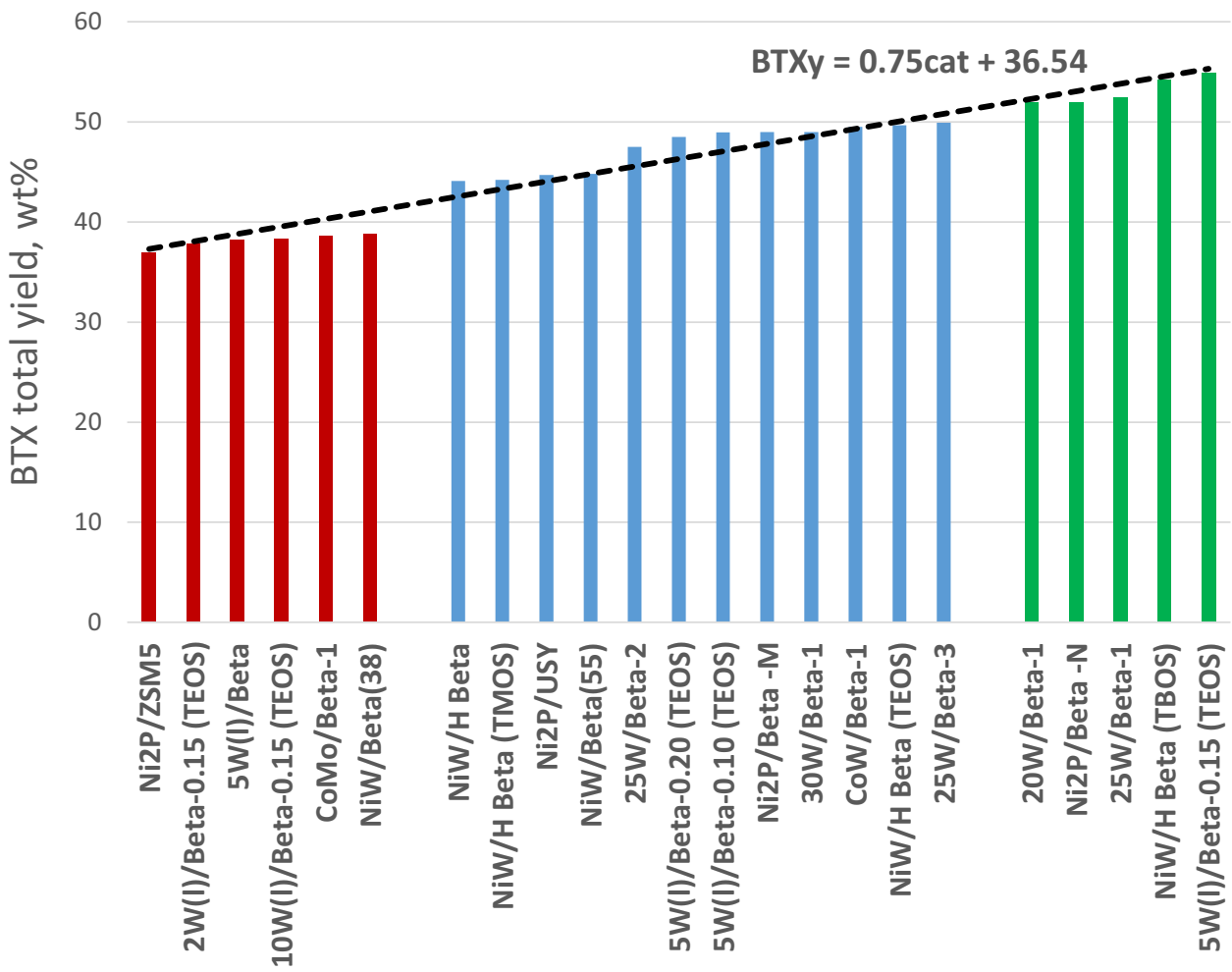

(LP: 10,10 , and $15 \%$ ) and $\mathrm{C}_{9+}$-alkylbenzenes $\left(\mathrm{C}_{9+} \mathrm{ALB}: 4\right.$, 0.5 , and $2 \%$ ) in the same order. Certainly, the differences in LHSVs were crucial for the BTX total yield increment in [24]. It is also interesting to observe, that with a real feed, the differences between BTX production were lower among the different catalysts tested, as compared to the experiments carried out with tetralin described in the 3.1 section.

Several metals such as NiMo, CoMo, and Mo were loaded (wet impregnation) onto $\mathrm{H}$-Beta $\left(\mathrm{SiO}_{2} / \mathrm{Al}_{2} \mathrm{O}_{3}\right.$ mole ratio $=75$ ) on hybrid zeolites by $\mathrm{Oh}$ et al. [34]. The hybrid zeolites were prepared by physically mixing the H-Beta (B) and $\mathrm{H}-\mathrm{ZSM}-5(\mathrm{Z})\left(\mathrm{SiO}_{2} / \mathrm{Al}_{2} \mathrm{O}_{3}\right.$ mole ratio=30) zeolites using different $\mathrm{H}-\mathrm{ZSM}-5$ amounts and will be referred to as $\mathrm{BZ}(\mathrm{x})$, hereafter $\mathrm{x}$ indicates the H-ZSM-5 content in \%. The zeolite-supported sulfide-metal catalysts were prepared by wet impregnation using $\mathrm{Co}\left(\mathrm{NO}_{3}\right)_{2} \cdot 6 \mathrm{H}_{2} \mathrm{O}, \mathrm{Ni}\left(\mathrm{NO}_{3}\right)_{2} \cdot 6 \mathrm{H}_{2} \mathrm{O}$, and $\left(\mathrm{NH}_{4}\right) 6 \mathrm{Mo}_{7} \mathrm{O}_{24} \cdot 4 \mathrm{H}_{2} \mathrm{O}$ as metal sources. The catalysts were tested at several experimental conditions to evaluate the best catalytic mixture and the catalyst that performed the best was tested at $425^{\circ} \mathrm{C}, 6 \mathrm{MPa}$, WHSV of $2 \mathrm{~h}^{-1}$, and 1975 $\mathrm{H}_{2}$ /feed volume ratio using a full range distillation hydrotreated light cycle oil (HDT LCO 2/1, Final boiling point $\left.(\mathrm{FBP})=386^{\circ} \mathrm{C}\right)$ and a fractionated hydrotreated light cycle oil (HDT LCO $2 / 2, \operatorname{FBP} 334^{\circ} \mathrm{C}$ ). When using the HDT LCO $2 / 1$, the BTX total yields were $29 \%$ for NiMo/BZ (10) and $\mathrm{Mo}(8) / \mathrm{BZ}$ (10) catalysts. No naphthalene, tetralin or indene derivatives were obtained at these experimental conditions. Light paraffins (LP: 17 and 29\%) and $\mathrm{C}_{9+}$-alkylbenzenes
$\left(\mathrm{C}_{9+} \mathrm{ALB}: 16\right.$ and $\left.16 \%\right)$ were formed. The incorporation of ZSM-5 into the hydrocracking catalyst was observed to increase the BTX yield, which promotes the dealkylation of alkylbenzenes to BTX [12]. When using the HDT LCO 2/2 with the $\mathrm{Mo} / \mathrm{BZ}(10)$ at the same experimental conditions, the total BTX, light paraffins (LP), and $\mathrm{C}_{9+}$-alkylbenzenes $\left(\mathrm{C}_{9+} \mathrm{ALB}\right)$ yields were $41.4,14$, and $13 \%$, respectively. Obviously, the fractionated LCO provides a better feed for the BTX production due to the reduction of tri-aromatic compounds that do not provide BTX by hydrocracking [7].

Laredo et al. [4] tested a 50/50 in weight mixture of two commercial catalysts: $\mathrm{NiMo} / \mathrm{Al}_{2} \mathrm{O}_{3}$ and $\mathrm{ZSM}-5$ that were prepared and tested with tetralin in a previous work [3] using, in this case, a fractionated hydrotreated light cycle oil (HDT LCO; FBP $=327^{\circ} \mathrm{C}$ ). At the best experimental conditions: fixed bed, $425^{\circ} \mathrm{C}, 7.4 \mathrm{MPa}, \mathrm{H}_{2} /$ feed ratio of 442 $\mathrm{m}^{3} / \mathrm{m}^{3}$, the BTX total yield was $31 \%$. Light hydrocarbons (LP: $32.4 \%)$ and $\mathrm{C}_{9+}$-alkylbenzenes $\left(\mathrm{C}_{9+} \mathrm{ALB}\right.$ : $\left.16 \%\right)$ were also formed. Indene, tetralin, and naphthalene derivatives were completely absent from the product. In this case, only the best catalyst was chosen from the previous experiments with tetralin [3].

Oh et al. [20] published the results of the hydrocracking of a hydrotreated light cycle oil (HDT LCO, FBP $\left.430{ }^{\circ} \mathrm{C}\right)$ with molybdenum $\left(8 \%,\left(\mathrm{NH}_{4}\right)_{6} \mathrm{Mo}_{7} \mathrm{O}_{24} \cdot 4 \mathrm{H}_{2} \mathrm{O}\right)$ on hybrid zeolites formed by $\mathrm{H}$-Beta $\left(\mathrm{SiO}_{2} / \mathrm{Al}_{2} \mathrm{O}_{3}=75\right)$, $\mathrm{HY}$ (FAU structure, $\left.\mathrm{SiO}_{2} / \mathrm{Al}_{2} \mathrm{O}_{3}=80\right)$ and HZSM-5 $\left(\mathrm{SiO}_{2} /\right.$ $\mathrm{Al}_{2} \mathrm{O}_{3}=30$ ) in $90 / 0 / 10,85 / 5 / 10$ and $80 / 10 / 10$ in weight 


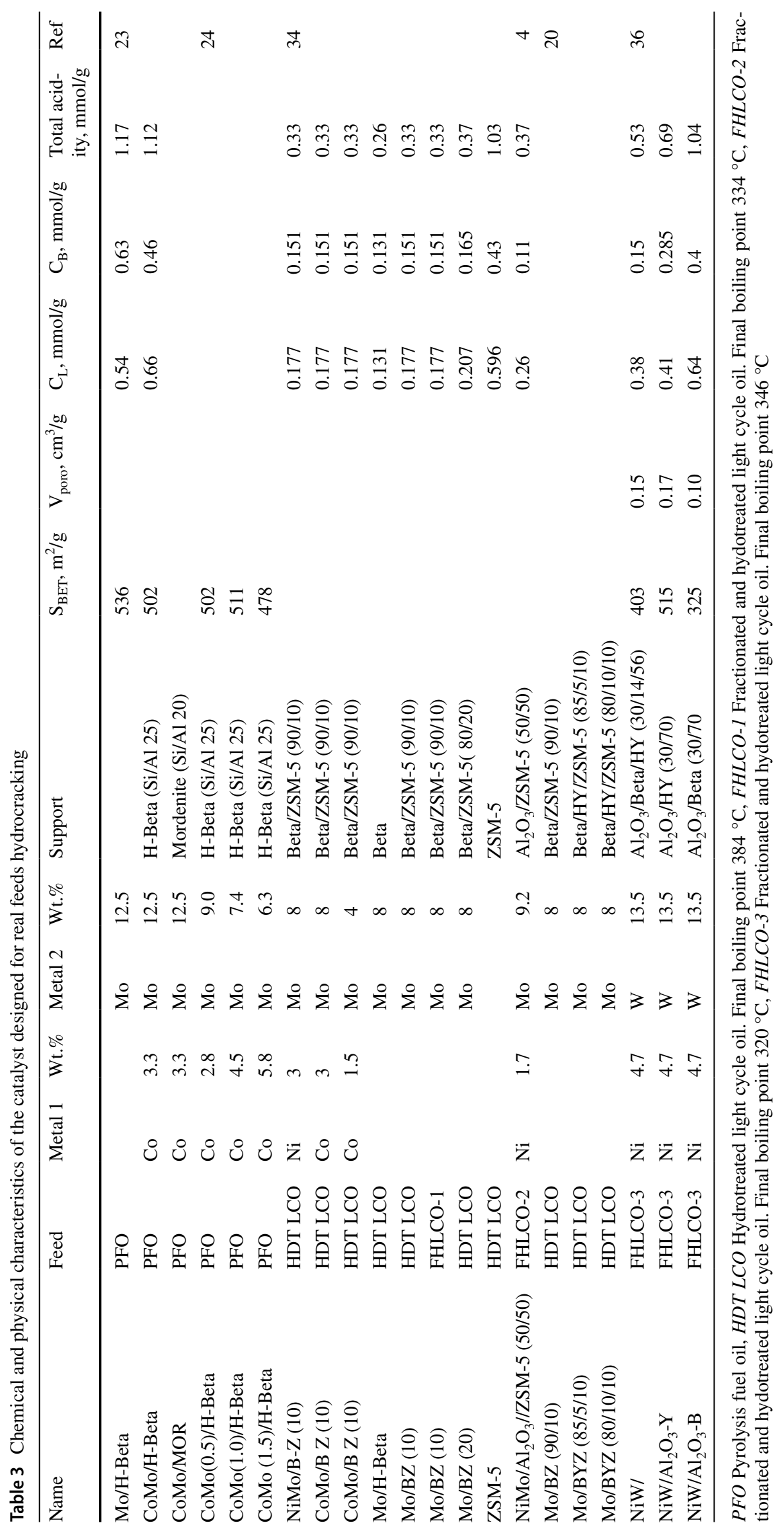


mechanical mixtures, supported by wet impregnation. The addition of the H-Y zeolite came from the conclusion that this mesoporous material can be useful on the hydrocracking of large tri-aromatic molecules than can be present in the HDT LCO. The hydrocracking process of the HDT LCO was carried out at the following experimental conditions: $425^{\circ} \mathrm{C}$, WHSV $=2.0 \mathrm{~h}^{-1}$, total pressure $=6.0 \mathrm{MPa}$, $\mathrm{H}_{2} /$ feed $=1972 \mathrm{~mL} / \mathrm{mL}$. The total BTX yield obtained with the Mo/BZ (90/10), Mo/BYZ (85/5/10), and Mo/BYZ $(80 / 10 / 10)$ were 25,27 , and $29 \%$. Other hydrocarbons in the products were, light paraffins (LP: 16, 16, and 14\%), $\mathrm{C}_{9+}$-alkylbenzenes $\left(\mathrm{C}_{9+} \mathrm{ALB}: 19,13\right.$, and $\left.9 \%\right)$, and some indanes and tetralin derivatives (TI: $1.1,0.7$, and $0.2 \%$ ). It is noteworthy that the differences in BTX yield between catalysts is not that important. The authors concluded that H-Beta was the most selective component for the hydrocracking of tetralin compounds, which were formed via the hydrotreating of the abundant naphthalene derivatives in LCO. H-ZSM-5, which had the highest acidity and smallest pore size, boosted the BTX yield by promoting the dealkylation/transalkylation of alkylbenzenes (which were co-produced via the hydrocracking of tetralin derivatives over H-Beta) into BTX. And the mesoporous H-Y facilitated the conversion of large molecular-size $\mathrm{C}_{11+}$ heavy aromatic compounds, which are too large to access the pores of H-Beta or H-ZSM.

Cao et al. [35] also used the CoMo/AY and NiMo/AY prepared catalyst for hydrocracking LCO and combined beds: first $\mathrm{NiMo} / \mathrm{AY}$ and then $\mathrm{CoMo} / \mathrm{AY}$ and vice versa. The experimental conditions for the two reactors (R1/R2) were: $385 / 400{ }^{\circ} \mathrm{C}, \mathrm{LHSV}=2.0 / 1.3 \mathrm{~h}^{-1}$, total pressure $=7 \mathrm{MPa}, \mathrm{H}_{2} /$ feed $=1000 \mathrm{~mL} / \mathrm{mL}$. Again, the aim was to produce gasoline and not BTX, the global BTX yields were low (8-13.2\%).

Very recent work by Anilkumar et al. [36] presented the results of the hydrocracking of a fractionated hydrotreated light cycle oil (HDT LCO, FBP $346{ }^{\circ} \mathrm{C}$ ) with a nickel (4.7\%) and tungsten $(13.5 \%)$ bifunctional catalyst obtained by wet impregnation of extrudates formed by the following mixtures: Cat-A $\left(\mathrm{Al}_{2} \mathrm{O}_{3} / \mathrm{Beta} / \mathrm{HY}(30 / 14 / 56)\right)$, Cat-B $\left(\mathrm{Al}_{2} \mathrm{O}_{3} / \mathrm{HY}\right.$ (30/70)) and Cat-C $\left(\mathrm{Al}_{2} \mathrm{O}_{3} / \mathrm{Beta}(30 / 70)\right)$. Total acidity of the catalyst followed the order (Table 3): Cat-A $<$ Cat-B $<$ Cat-C as well as the monoaromatic hydrocarbons productions: 12 , 22 , and $44.3 \mathrm{wt} \%$ at $350{ }^{\circ} \mathrm{C}, 6 \mathrm{MPa}, \mathrm{H}_{2} /$ feed ratio of $10 \mathrm{~mol} /$ mol and $1 \mathrm{~h}^{-1}$ WHSV. The authors claimed that the combination of dispersed metallic sites and high acidity contributed to the high hydrocracking activity of catalyst-C $[1,2$, 10-12, 14]. This data could not be used in the comparison with the other results described in this work, because these authors compiled all the monoaromatic hydrocarbons as one group without differentiating the BTX from the other higher molecular weight $\mathrm{C}_{9+}$-alkylaromtics. In this review, only the $\mathrm{C}_{6}-\mathrm{C}_{8+}$ (including ethylbenzene) were considered in the comparison.

\section{Partial conclusions}

Figure 8 shows some of the more important results. Departing from real feeds a total BTX yield higher than $35 \%$ was never attained using a hydrocracking catalyst of any type, due to the presence of another type of competing hydrocarbons [7], and the inevitable gas formation and other $\mathrm{C}_{9+}$-alkylbenzenes formed [26]. Considering that all the aromatic compounds (alkylbenzene, tetralin, naphthalene,
Fig. 8 Main results for the effect of the catalyst in the BTX total yield from real feeds hydrocracking

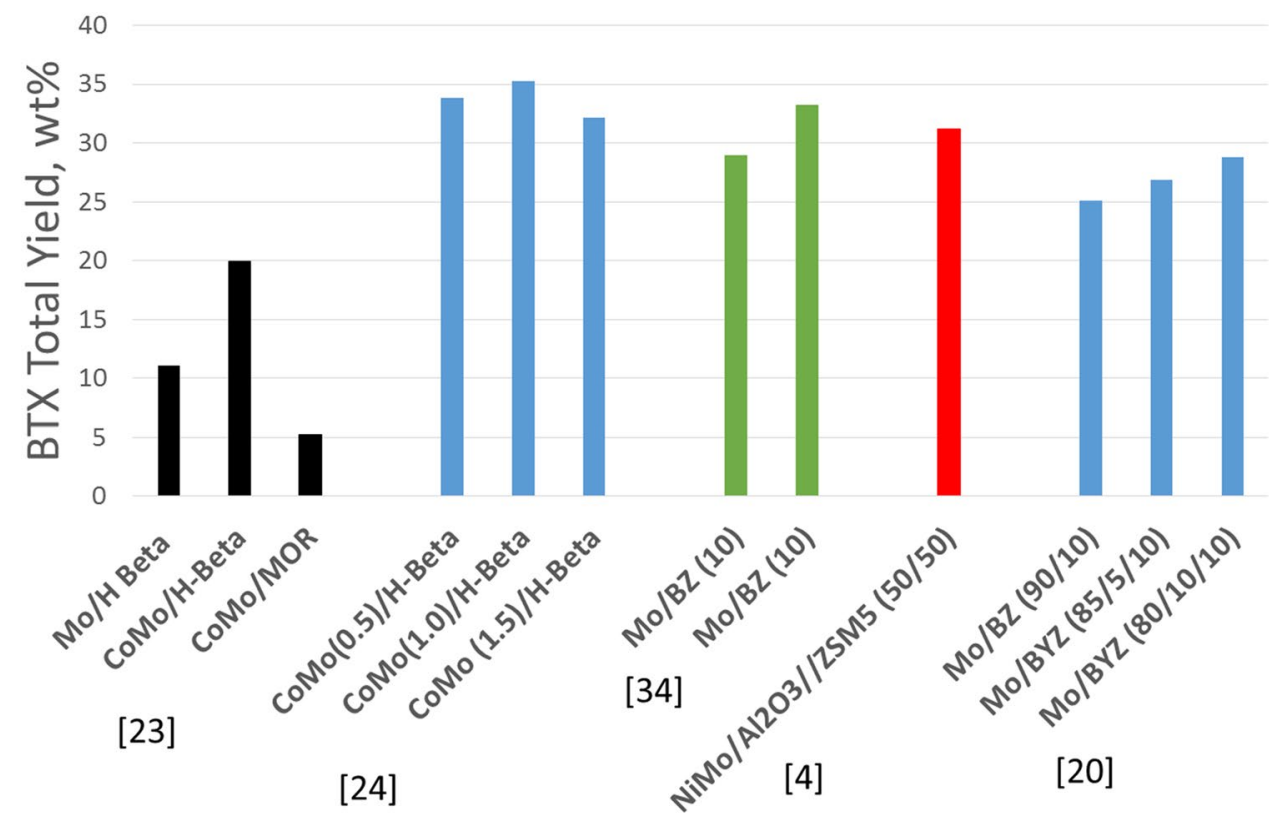


indane, and indene aromatic compounds) may have the capacity to be converted to BTX by hydrocracking and transalkylation reactions [4], and they can be present from 30 to up to $90 \%$ in a real feed [7], the theoretical yield should be approximately thirty to nighty percent of the theoretical conversions (63-65\%) then equal to $19-55 \%$, depending on the feed. A study regarding feed composition and BTX yield is in progress and it will be presented in the future, however, certainly not all the aromatic compounds available for conversion to BTX are chemically suitable for performing such a task.

The only correlation slightly logic was the effect of the metal content on the catalyst, in the BTX total yield (Fig. 9). In this case, is important to notice the required metal dispersion for carrying on several tasks [12]. It seems that the hydrocracking reaction for the BTX conversion from real feedstocks will require as much as possible from the hydrocracking properties related to the support like acid sites and pore structure rather than the hydrogenation properties related to the supported metals. However, is exceedingly difficult to assess the catalytic performance that requires the combined performance of two active sites (bifunctional catalyst) on the hydrocracking of extraordinarily complex real feedstocks.

Therefore, for the purposes of this work, the best catalysts were those conformed by Mo, CoMo, or NiMo over zeolite H-Beta (Fig. 10). Some researchers [34] found that adding some of ZSM-5 to the H-Beta can improve the BTX formation. A mixture of catalysts in which one of them was ZSM-5 [4] was also useful. Some authors claimed [20] that a small amount of a mesoporous material like H-Y improves the BTX yield by facilitating the diffusion of large molecules, like the tri + aromatic compounds that can be found in real feeds, such as the hydrotreated light cycle oil. Finally, Fig. 10 shows that the slope is steeper between the first group that covers the worst performing catalysts for BTX yield (5-13 wt.\%) and the best performance group (30-35\%) of catalysts. This behavior means that the catalysts found using model molecules are not always reliable for their use in a real feed.

Anyhow, there is a strong possibility that this type of feedstocks still will be usable despite of the yield, due to the general trend to convert fossil fuels to petrochemicals.

\section{Reaction scheme, future trends, and economic development of this process}

Real feeds upgrading by hydrocracking for obtaining valuable petrochemicals like BTX faces, as far as it was observed, an economic challenge due to the low BTX yield that all types of feeds, catalysts, and experimental conditions seem to provide. Based on the information compiled in this work, a reaction scheme was proposed (Fig. 11). Perhaps, the only possible route for increasing the BTX yield, would be finding a way for increasing disproportionation, and transalkylation reactions [37-40] that increase the formation of BTX from $\mathrm{C}_{9+}$-alkylbenzenes (increasing $k_{D T}$ reaction rate) that according to this scheme, are formed at the same time, and that now are considered by-products. Disproportionation and transalkylation are the two major practical processes for the interconversion of alkylaromatics, especially for the production of dialkylbenzenes $[39,40]$. The contribution of these two mechanisms to the overall process depends on the relative stability of the alkylaromatic and bulkier diaryl cationic intermediates and is largely influenced by the reactant size, zeolite pores, and the presence of channel intersections or cavities [41].

However, as the worldwide trend continues in the search for the substitution of crude oil fuels for more environmentally friendly energy sources, the research for petrochemical production from all kinds of crude oils (light or heavy) is going to increase sharply. It is on this demand where low marketable feeds may find a profitable niche. According to Tulio [42], and it is quoted: "The driver this time is the market more than it is cheap raw material supply. By 2030, demand for gasoline and other fuels will be on the decline.
Fig. 9 Effect of the total metal content on the BTX total yield from real feeds hydrocracking

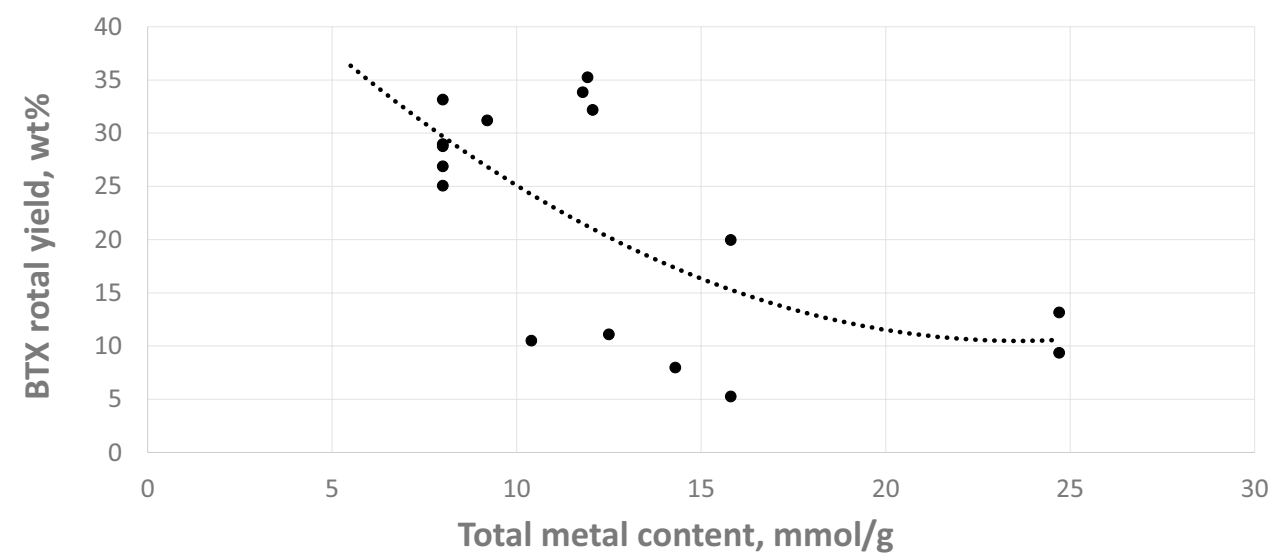

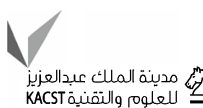
Springer 
Fig. 10 Worst to the best catalyst for real feeds hydrocracking for BTX production
Fig. 11 Suggested reaction scheme for the HCK of the HDT LCO
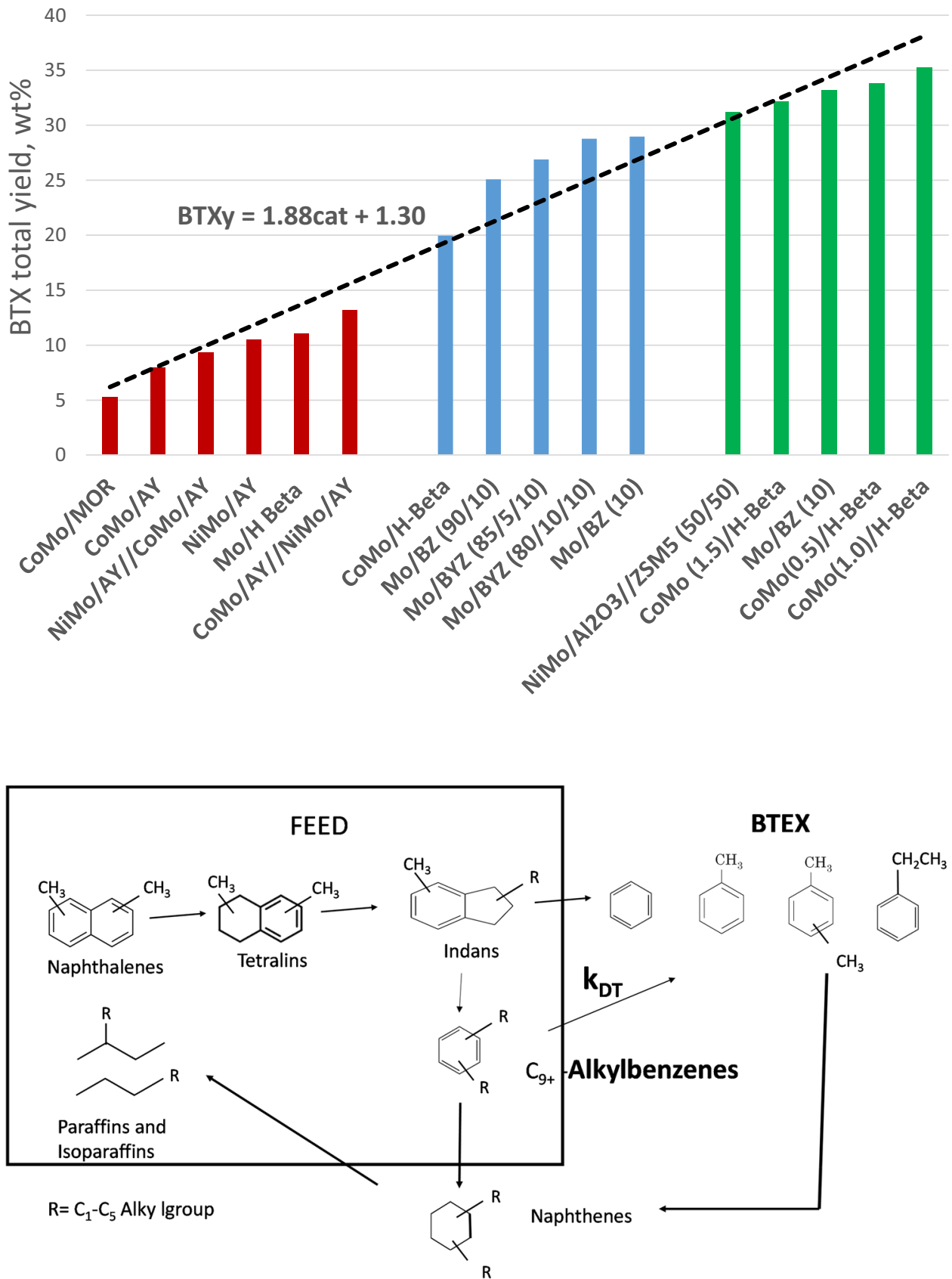

The petrochemical sector, in contrast, still has room to grow. Oil companies and engineering firms have noticed. They are installing new equipment and even designing new processes to seize on the trend.". Therefore, it is hope for this technology even as it is now.

\section{General conclusions}

A total BTX yield of 53-55\% was obtained by the hydrocracking of tetralin and naphthalene derivatives. Higher yields were never attained due to the inevitable gas formation and other $\mathrm{C}_{9+}$-alkylbenzenes formed. For tetralin, the best catalysts are those conformed by $\mathrm{Ni}, \mathrm{CoMo}$, NiMo, or NiSn over zeolite H-Beta. The adding a $10 \%$ 
in weight of ZSM-5 to the H-Beta, the BTX formation can be improved. For naphthalene derivatives, the best catalysts were those conformed by $\mathrm{W}$ and NiW over zeolite H-Beta silylated. While departing from real feeds a total BTX yield higher of $35 \%$ was never attained using a hydrocracking catalyst of any type, due to the presence of other types of hydrocarbons from the feed. The best catalysts were those conformed by Mo, CoMo, or NiMo over zeolite H-Beta. The presence of ZSM-5 and H-Y in the support or/as catalyst mixture was claimed to show some improvements in the BTX yield, especially the last one with larger pores, which can facilitate the diffusion of larger molecules like the tri +-ring aromatic molecules which can be present in the real feeds. A balance between acid and hydrogenating function with the right accessibility characteristics to the sites appears to be needed to obtain a high BTX yield.

Acknowledgements The authors are grateful for the financial support provided by the Mexican Petroleum Institute, Mexico. Eli Hazel Olmos Cerda is grateful for the scholarship provided by the CONACYT-México.

Author contributions GCL conceived the review, PPR, JLGG, and EHOC revised the information.

\section{Compliance with ethical standards}

Conflict of interest The authors declare no conflict of interest.

Open Access This article is licensed under a Creative Commons Attribution 4.0 International License, which permits use, sharing, adaptation, distribution and reproduction in any medium or format, as long as you give appropriate credit to the original author(s) and the source, provide a link to the Creative Commons licence, and indicate if changes were made. The images or other third party material in this article are included in the article's Creative Commons licence, unless indicated otherwise in a credit line to the material. If material is not included in the article's Creative Commons licence and your intended use is not permitted by statutory regulation or exceeds the permitted use, you will need to obtain permission directly from the copyright holder. To view a copy of this licence, visit http://creativecommons.org/licenses/by/4.0/.

\section{References}

1. Laredo GC, Pérez-Romo P, Escobar J, García-Gutiérrez JL, VegaMerino P (2017) Light cycle oil upgrading to benzene, toluene and xylenes by hydrocracking: studies using model mixtures. Ind Eng Chem Res 56:10939-10948. https://doi.org/10.1021/acs. iecr.7b02827

2. Laredo GC, Vega-Merino PM, Schacht-Hernández P (2018) Light cycle oil upgrading to high quality fuels and petrochemicals: a review. Ind Eng Chem Res 57:7315-7321. https://doi. org/10.1016/j.cattod.201509.046

3. Laredo GC, Pérez-Romo P, Vega-Merino PM, Arzate-Barbosa E, García-López A, Agueda-Rangel R, Martínez-Moreno VH (2019) Effect of the catalytic system and operating conditions on BTX formation using tetralin as a model molecule. Appl Petrochem Res 9:185-198. https://doi.org/10.1007/s13203-019-00237-4

4. Laredo GC, Pérez-Romo P, Agueda-Rangel R, García-López A (2020) Effect of the experimental conditions on BTX formation from hydrotreated light cycle oil. Appl Petrochem Res 10:21-34. https://doi.org/10.1007/s13203-020-00242-y

5. Stanislaus A, Marafi A, Rana MS (2010) Recent advances in the science and technology of ultra-low sulfur diesel (ULSD) production. Catal Today 153:1-68. https://doi.org/10.1016/j.catto d.2010.05.011

6. Laredo GC, Figueroa Y, Cano JL, Mares MT, Castillo J (2002) Estudio de la composición del aceite cíclico ligero provenientes de crudos mexicanos. J Mex Chem Soc 46:115-119

7. Laredo GC, Pérez-Romo P, Agueda-Rangel R, Escobar J, VegaMerino P (2020) Detailed characterization of light cycle oil for BTX production purposes. Int J Petrol Petrochem Eng 6:1-12. https://doi.org/10.20431/2454-7980.0603001

8. Environmental Protection Agency Diesel fuel standards and rulemakings. https://www.epa.gov/diesel-fuel-standards/diesel-fuelstandards-and-rulemakings. Accessed on Sep 15, 2020.

9. European Automobile Manufacturers Association. Worldwide fuel charter - ACEA. https://fliphtml5.com/twsl/iert. Accessed on Sep 15, 2020.

10. Bisht D, Petri J (2014) Considerations for upgrading light cycle oil with hydroprocessing technologies. Indian Chem Eng 56:321335. https://doi.org/10.1080/00194506.2014.927179

11. Park J-I, Ali SA, Alhooshani K, Azizi N, Miyawaki J, Kim T, Lee Y, Kim H-S, Yoon S-H, Mochida I (2013) Mild hydrocracking of 1-methyl naphthalene (1-MN) over alumina modified zeolite. J Ind Eng Chem 19:627-632. https://doi.org/10.1016/j.jiec.2012.09.014

12. Saab R, Polychronopoulou K, Li Z, Kumar S, Schiffer A (2020) Synthesis and performance evaluation of hydrocracking catalysts: a review. J Ind Eng Chem 89:83-103. https://doi.org/10.1016/j. jiec.2020.06.022

13. Baudon A, Lemberton JL, Guisnet M, Marchal N, Mignard S (1996) Hydrocracking of $n$-heptane on a Sulfide NiMo-Y zeolite catalyst: effect of the sulfidation method. Catal Letter 36:245-247. https://doi.org/10.1007/BF00807627

14. Charisiou ND, Polychronopoulou K, Asif A, Goul MA (2018) The potential of glycerol and phenol towards $\mathrm{H}_{2}$ production using steam reforming reaction: a review. Surf Coat Techn 352:92-111. https://doi.org/10.1016/j.surfcoat.2018.08.008

15. Busca G (2017) Acidity and basicity of zeolites: a fundamental approach. Microporous Mesoporous Mater 254:3-16. https://doi. org/10.1016/j.micromeso.2017.04.007

16. Sato K, Iwata Y, Yoneda T, Nishijima A, Miki Y, Shimada H (1998) Hydrocracking of diphenylmethane and tetralin over bifunctional NiW sulfide catalysts supported on three kinds of zeolites. Catal Today 45:367-374. https://doi.org/10.1016/S0920 -5861(98)00266-1

17. Sato K, Iwata Y, Miki Y, Shimada H (1999) Hydrocracking of tetralin over NiW/USY zeolite catalysts: for the improvement of heavy-oil upgrading catalysts. J Catal 186:45-56. https://doi. org/10.1006/jcat.1999.2546

18. Ferraz SGA, Zanon Zotina FM, Raddi Araujo LR, Zoti JL (2010) Influence of support acidity of NiMoS catalysts in the activity for hydrogenation and hydrocracking of tetralin. Appl Catal A 384:51-57. https://doi.org/10.1016/j.apcata.2010.06.003

19. Sato K, Nishimura Y, Honna K, Matsubayashi N, Shimada H (2001) Role of HY zeolite mesopores in hydrocracking of heavy oils. J Catal 200:288-297. https://doi.org/10.1006/jcat.2001.3184

20. Oh Y, Noh H, Park H, Han H, Nguyen T-B, Lee J-K (2020) Molecular-size selective hydroconversion of FCC light cycle oil into petrochemical light aromatic hydrocarbons. Catal Today 352:329-336. https://doi.org/10.1016/j.cattod.2019.08.037

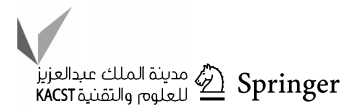


21. Choi Y, Lee J, Shin J, Lee S, Kim D, Lee JK (2015) Selective hydroconversion of naphthalenes into light alkyl-aromatic hydrocarbons. Appl Catal A 492:140-150. https://doi.org/10.1016/j. apcata.2014.12.0

22. Lee J, Choi Y, Shin J, Jung KL (2016) Selective hydrocracking of tetralin for light aromatic hydrocarbons. Catal Today 265:144153. https://doi.org/10.1016/j.cattod.2015.09.046

23. Upare DP, Park S, Kim MS, Kim J, Lee D, Lee J, Chang H, Choi W, Choi S, Jeon Y-P, Park Y-K, Lee CW (2016) Cobalt promoted $\mathrm{Mo} /$ beta zeolite for selective hydrocracking of tetralin and pyrolysis fuel oil into monocyclic aromatic hydrocarbons. J Ind Eng Chem 35:99-107. https://doi.org/10.1016/j.jiec.2015.12.020

24. Upare DP, Park S, Kim MS, Jeon Y-P, Kim J, Lee D, Lee J, Chang H, Choi S, Choi W, Park Y-K, Lee CW (2017) Selective hydrocracking of pyrolysis fuel oil into benzene, toluene and xylene over CoMo/beta zeolite catalyst. J Ind Eng Chem 46:356-363. https:// doi.org/10.1016/j.jiec.2016.11.004

25. Shin J, Oh Y, Choi Y, Lee J, Lee JK (2017) Design of selective hydrocracking catalysts for BTX production from diesel-boilingrange polycyclic aromatic hydrocarbons. Appl Catal A 547:12-21. https://doi.org/10.1016/j.apcata.2017.08.019

26. Arribas MA, Martínez A (2002) The influence of zeolite acidity for the coupled hydrogenation and ring-opening of 1-methylnaphthalene on Pt/USY catalyst. Appl Catal A 230:203-217. https:// doi.org/10.1016/S0926-860X(01)01015-8

27. Kim Y-S, Yun G-N, Lee Y-K (2014) Novel Ni2P/zeolite catalyst for the hydrocracking. Catal Comm 45:133-138. https://doi. org/10.1016/j.catcom.2013.11.010

28. Kim ES, Lee Y, Kim JR, Kim JW, Kim TW, Chae HJ, Kim CU, Lee CH, Jeong SY (2016) Selective ring-opening of 1-methylnaphthalene over $\mathrm{NiW}$-supported catalyst using dealuminated beta zeolite. J Nanosci Nanotechnol 16:1715-1719. https://doi. org/10.1166/jnn.2016.11997

29. Lee YJ, Kim ES, Kim JR, Kim JW, Kim TW, Chae HJ, Kim CU, Lee CA, Jeong SY (2016) The Effect of K and Acidity of NiWLoaded HY zeolite catalyst for selective ring-opening of 1-Methylnaphthalene. J Nanosci Nanotechnol 16:4335-4341. https://doi. org/10.1166/jnn.2016

30. Lee S-U, Lee Y-J, Kim J-R, Jeong S-Y (2017) Rational synthesis of silylated Beta zeolites and selective ring-opening of 1-methylnaphthalene over the NiW-supported catalysts. Appl Catal B 219:1-9. https://doi.org/10.1016/j.apcatb.2017.07.047

31. Kim Y-S, Cho K-S, Lee Y-K (2017) Morphology effect of $\beta$-zeolite supports for $\mathrm{Ni}_{2} \mathrm{P}$ catalysts on the hydrocracking of polycyclic aromatic hydrocarbons to benzene, toluene, and xylene. J Catal 351:67-78. https://doi.org/10.1016/j.jcat.2017.03.006

32. Wu T, Chen SL, Yuan GM, Xu J, Huang LX, Cao YQ, Fan TT (2018) High-selective-hydrogenation activity of W/Beta catalyst in hydrocracking of 1-methylnaphthalene to benzene, toluene, and xylene. Fuel 234:1015-1025. https://doi.org/10.1016/j. fuel.2018.07.133

33. Wu T, Chen S-L, Yuan G-M, Pan X, Du J, Zhang Y, Zhang N (2020) High metal-acid balance and selective hydrogenation activity catalyst for hydrocracking of 1-methnaphthalene to benzene, toluene, and xylene. Ind Eng Chem Res 59:5546-5556. https:// doi.org/10.1021/acs.iecr.9b06158

34. Oh Y, Shin J, Noh H, Kim C, Kim Y-S, Lee YK, Lee JK (2019) Selective hydrotreating and hydrocracking of FCC light cycle oil into high-value light aromatic hydrocarbons. Appl Catal A 577:86-98. https://doi.org/10.1016/j.apcata.2019.03.004

35. Cao Z, Zhang X, Xu C, Huang X, Wub Z, Peng C, Duan A (2021) Selective hydrocracking of light cycle oil into high-octane gasoline over bi-functional catalysts. J Energy Chem 52:41-50. https ://doi.org/10.1016/j.jechem.2020.04.055

36. Anilkumar M, Loke N, Patil V, Panday R, Sreenivasarao G (2020) Hydrocracking of hydrotreated light cycle oil to mono aromatics over non-noble bi-functional (ni-w supported) zeolite catalysts. Catal Today 358:221-227. https://doi.org/10.1016/j.catto d.2019.12.027

37. Townsend AT, Abbot J (1993) Catalytic reactions of tetralin on HZSM-5 zeolite. App Catal A 95:221-236. https://doi. org/10.1016/0926-860X(93)85076-2

38. Tsai T-C, Lin S-B, Wang I (1999) Disproportionation and transalkylation of alkylbenzenes over zeolite catalyst. Appl Catal A Gral 181:355-398. https://doi.org/10.1016/S0926 -860X(98)00396-2

39. Mokoena K. Alkyl transfer (transalkylation) reactions of alkylaromatics on solid acid catalysis. PhD Thesis. University of the Witwatersrand, Johannesburg. http://wiredspace.wits.ac.za/bitstream/ handle/10539/1751/ALKYL_TRANSDFER_TRANSALKYL . PDF? sequence $=1 \&$ isAllowed $=y$. Accessed on January 22, 2021

40. Huang J, Jiang Y, Marthala VRR, Hunger M (2008) Insight into the mechanisms of the ethylbenzene disproportionation: transition state shape selectivity on zeolites. J Am Chem Soc 130(38):12642-12644. https://doi.org/10.1021/ja8042849

41. Margarit VJ, Osman M, Al-Khattaf S, Martínez C, Boronat M, Corma A (2019) Control of the reaction mechanism of alkylaromatics transalkylation by means of molecular confinement effects associated to zeolite channel architecture. ACS Catal 9:59355946. https://doi.org/10.1021/acscatal.9b00763

42. Tulio A. H. (2019) Why the future of oil is in chemicals, not fuels. 9 (8). https://cen.acs.org/business/petrochemicals/future-oil-chemi cals-fuels/97/i8

Publisher's Note Springer Nature remains neutral with regard to jurisdictional claims in published maps and institutional affiliations 